\title{
Targeting the Microenvironment in High Grade Serous Ovarian Cancer
}

\author{
Nkechiyere G. Nwani ${ }^{1}$, Livia E. Sima ${ }^{1}$ (D), Wilberto Nieves-Neira ${ }^{1,2}$ and Daniela Matei ${ }^{1,2, *}$ \\ 1 Department of Obstetrics and Gynecology, Northwestern University, Chicago, IL 60611, USA; \\ Nnwani@northwestern.edu (N.G.N.); Livia.sima@northwestern.edu (L.E.S.); \\ wilberto.nieves-neira@nm.org (W.N.-N.) \\ 2 Robert H. Lurie Comprehensive Cancer Center, Chicago, IL 60611, USA \\ * Correspondence: daniela.matei@northwestern.edu
}

Received: 20 July 2018; Accepted: 6 August 2018; Published: 10 August 2018

\begin{abstract}
Cancer-stroma interactions play a key role in cancer progression and response to standard chemotherapy. Here, we provide a summary of the mechanisms by which the major cellular components of the ovarian cancer (OC) tumor microenvironment (TME) including cancer-associated fibroblasts (CAFs), myeloid, immune, endothelial, and mesothelial cells potentiate cancer progression. High-grade serous ovarian cancer (HGSOC) is characterized by a pro-inflammatory and angiogenic signature. This profile is correlated with clinical outcomes and can be a target for therapy. Accumulation of malignant ascites in the peritoneal cavity allows for secreted factors to fuel paracrine and autocrine circuits that augment cancer cell proliferation and invasiveness. Adhesion of cancer cells to the mesothelial matrix promotes peritoneal tumor dissemination and represents another attractive target to prevent metastasis. The immunosuppressed tumor milieu of HGSOC is permissive for tumor growth and can be modulated therapeutically. Results of emerging preclinical and clinical trials testing TME-modulating therapeutics for the treatment of OC are highlighted.
\end{abstract}

Keywords: high-grade serous ovarian cancer; tumor microenvironment; angiogenesis; immune response; metastasis; therapeutic targeting strategies

\section{Introduction}

High-grade serous ovarian cancer (HGSOC) comprises the majority of epithelial ovarian tumors, is associated with a p53-mutated signature and is characterized by initial sensitivity to platinum and a unique pattern of dissemination in the peritoneal space. The peritoneum consists of mesothelial cells that cover and protect the viscera. The sub-peritoneal stroma contains a collagen-based matrix, activated fibroblasts, blood vessels, and lymphatics. This unique milieu permits accumulation of factors secreted by both cancer and stromal cells and enables metastatic seeding and tumor proliferation. The immune component of the peritoneal milieu consists of monocytes/macrophages and cytotoxic T cells. Several studies have demonstrated an "activated" phenotype of the peritoneal environment associated with ovarian cancer (OC), as opposed to its quiescent state in benign conditions [1]. The pro-inflammatory signature associated with cancer favors angiogenesis and exerts chemotactic and protective effects on cancer cells. Chemokines, cytokines, and growth factors commonly secreted in the tumor microenvironment (TME) include the stromal cell-derived factor (SDF1), interleukin-6 (IL-6), interleukin (IL-8), monocyte chemoattractant protein 1 (MCP1), Chemokine (C-C motif) ligand 5 and 7 (CCL5 and CCL7), transforming growth factor- $\beta 1$ TGF $\beta 1$, tumor necrosis factor- $\alpha$ (TNF $\alpha)$, fibroblast growth factor (FGF), and others [1-4]. While tumor cells play a role in the secretion of factors that modulate angiogenesis, non-transformed tumor infiltrating cells such as fibroblasts, myeloid cells, immune cells, and endothelial precursors also play a crucial role modulating neo-vascularization [5]. 
OC metastasis commonly involves the omentum, an adipocyte-rich organ. Lipid transfer between adipocytes and cancer cells mediated by fatty acid binding protein 4 (FABP4), through a "symbiotic" process between cancer cells and the fatty microenvironment was described as a key regulator of peritoneal metastasis [6]. As the rich TME protects cancer cells from noxious stimuli promoting tumor growth (Figure 1), its disruption through targeted therapy could arrest cancer progression. Indeed, over the past decade, several classes of novel agents targeting the ovarian TME have been developed and tested clinically. The most active agents are antiangiogenic therapies, which have been recently approved by the Food and Drug Administraton FDA for OC. Other emerging strategies, particularly immunotherapy, are in various stages of development. Here, several targeted therapies directed against the main components of the TME will be reviewed.

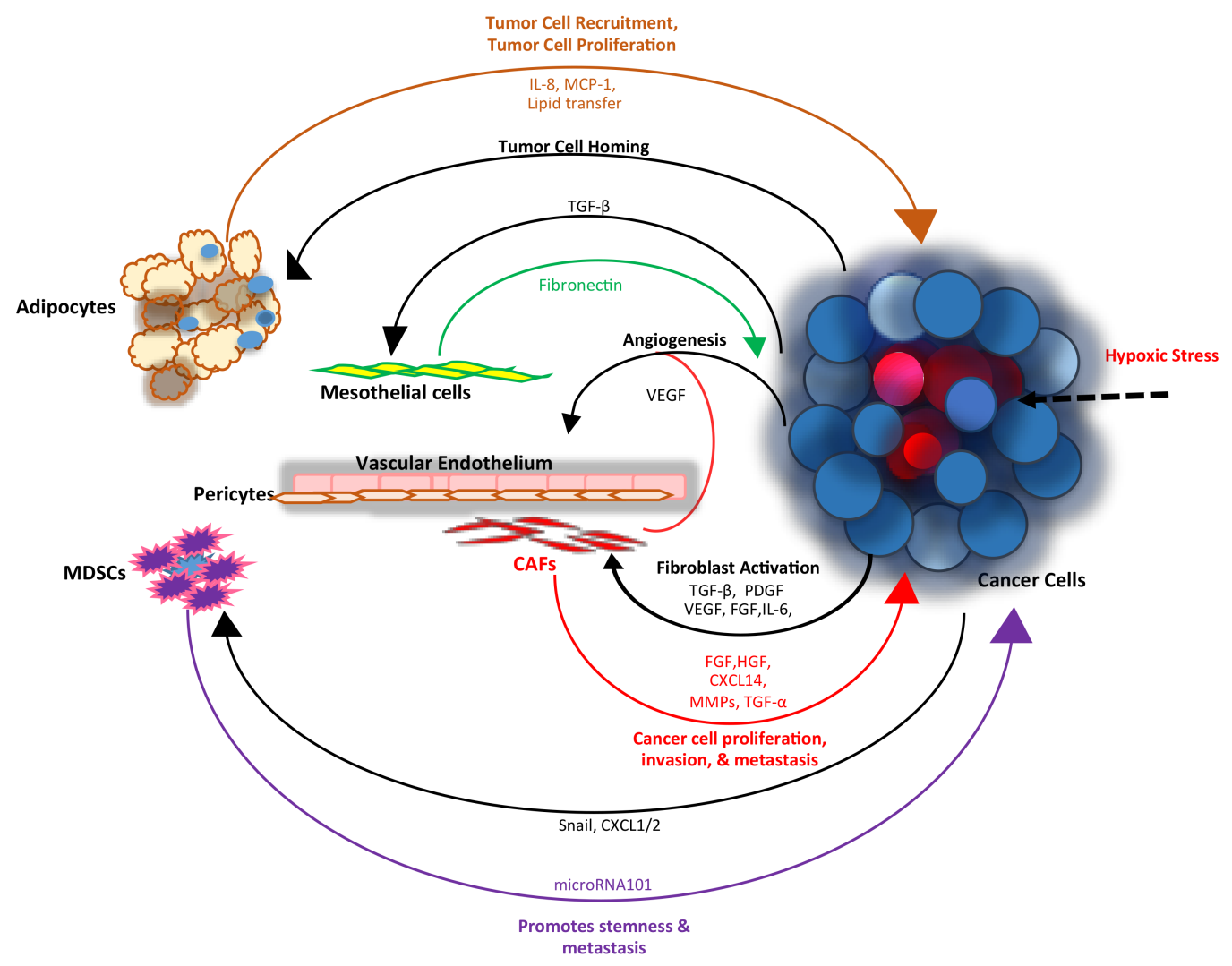

Figure 1. The interplay between cancer and stromal cells in the tumor microenvironent TME regulates tumor growth and metastasis: as tumors grow, hypoxic stress and low nutrient availability drives the release of tumor-secreted growth factors and cytokines that exert paracrine effects on the surrounding stroma. Sustained exposure to tumor-derived transforming growth factor- $\beta$ (TGF- $\beta$ ), platelet-derived growth factor (PDGF), fibroblast growth factor (FGF) and vascular endothelial growth factor (VEGF) drives fibroblasts trans-differentiation into (cancer associated fibroblasts) CAFs. These factors also act upon endothelial cells, pericytes and immune cells to stimulate angiogenesis. CAF-derived FGF and hepatocyte growth factor (HGF) promote tumor cell proliferation, CAF-derived matrix metalloproteinases (MMPs) promote invasion while chemokine ligand 14 (CXCL14) and transforming growth factor- $\alpha$ (TGF- $\alpha$ ) enhance metastasis. Ovarian cancer (OC) cell-derived TGF- $\beta 1$ upregulates fibronectin secretion in mesothelial cells, which in turn enhances spheroid adhesion to the peritoneal wall. Adipocytes facilitate cells proliferation by providing energy dense lipids to the metastasized cancer cells. Cancer cells expressing Snail and chemokine (C-X-C motif) ligand 1/2 (CXCL1/2) recruit myeloid-derived suppressor cells (MDSCs) to the tumor site; conversely MDSC-secreted microRNA101 reprograms tumor cells to a stemness phenotype. 


\section{Fibroblasts}

Fibroblasts represent the preeminent cellular component of connective tissues, the structural scaffold of many organs in the body. They are a heterogeneous population of mesenchymal-derived cells that maintain the composition of the extracellular matrix (ECM) $[7,8]$. As such, fibroblasts produce and deposit most of the proteins that comprise the ECM, including collagens, proteoglycans, tenascin, fibronectin, and laminin. Tissue homeostasis involves a tightly orchestrated balance of ECM synthesis and metabolism; in addition to ECM production, fibroblasts are also responsible for matrix metabolism. They produce several ECM-degrading matrix metalloproteinases (MMPs) and their inhibitors, tissue inhibitors of metalloproteinases (TIMPs) [9]. It has been observed that fibroblasts within the tumor milieu are phenotypically similar to activated fibroblasts associated with granulating tissue (wound healing) [10]. These cancer-associated fibroblasts (CAFs) function as tumor-promoting cells; playing important roles in tumor initiation and progression [11-13]. Although resident fibroblasts are a major source of CAFs, they can also arise from the trans-differentiation of other cell populations including epithelial cells, endothelial cells, pericytes, adipocytes and bone marrow-derived mesenchymal stem cells [14]. During tumorigenesis the trans-differentiation of the aforementioned cells into CAFs is driven by sustained exposure to tumor-derived factors including TGF- $\beta$, PDGF-BB, basic fibroblast growth factor (bFGF), vascular endothelial growth factor (VEGF), as well as microRNAs, reactive oxygen species (ROS), matrix metalloproteases (MMPs) and extracellular vesicles [15-19].

Current evidence suggests the mechanisms/downstream effectors that coordinate CAF activation vary and are contingent on CAF origin. For example, it was shown that SKOV3 cells stimulate normal fibroblasts conversion through TGF- $\beta$ mediated induction of ROS and CLIC4, which led to the subsequent increase in the expression CAF markers $\alpha$ SMA and FAP. On the other hand, Jeon et al., demonstrated that cancer cell-derived lysophosphatidic acid induced TGF- $\beta$ in adipose tissue-derived mesenchymal stem cells which then promoted their trans-differentiation into CAFs $[18,20]$. Likewise, expression of HOXA9, a differentiation related gene, was linked to paracrine secretion of TGF- $\beta 2$ by OC cells, inducing adipose and mesenchymal stem cells to become CAFs [21]. It is unknown whether other stromal cells such as pericytes and endothelial could also contribute to the reactive stroma associated with HGSOC.

The role of fibroblasts in cancer progression is complex. Early studies provided evidence that fibroblasts possess anti-tumorigenic function by forming a restrictive stroma. However, the atypical cancer-stroma interactions promote fibroblasts to develop tumor-permissive properties [22-24]. Recent reports illustrate how the reciprocal cancer cell-fibroblast communication potentiates tumor growth and progression in OC models. For example, CAFs have been shown to suppress the immune response through miR141/200a-mediated expression of CAF-derived CXCL12. This chemokine promotes infiltration of immunosuppressive $\mathrm{CD} 25^{+} \mathrm{FOXP}^{+} \mathrm{T}$ lymphocytes in the HGSOC milieu, which in turn allows tumor growth [25]. CAFs have also been shown to drive tumor cell proliferation, migration and invasion by producing high amounts of mitogenic factors, hepatocyte growth factor (HGF) and FGF [26-28]. Additionally, CAF-secreted IL-8 and SDF-1 drive angiogenesis to facilitate oxygen and nutrients delivery to the tumor tissue $[29,30]$. Fibroblasts treated with SKOV3-derived extracellular vesicles acquired an activated phenotype; in turn these fibroblast enhanced tumor and endothelial cells proliferation [17]. In another study, OC cell-derived TNF- $\alpha$ induced TGF- $\alpha$ transcription in stromal fibroblasts. In turn, TGF- $\alpha$ secreted by these fibroblasts promoted metastasis via induction of EGFR signaling in cancer cells [31]. CAFs also produce metabolites that are essential to cancer cells' survival, such as lactate that is absorbed and utilized by oxidative phosphorylation in adjacent cancer cells [32]. The chemokine ligand 14 (CXCL14) is a CAFs secreted protein that is associated with a poor prognosis in OC. It was discovered that CXCL14 induced LINC00092 expression in OC cells, which resulted enhanced metastasis. LINC0009 interacted with 6-phosphofructo-2-kinase/fructose-2,6-biphosphatase 2 (PFKFB2) to induce a glycolytic phenotype in ovarian cancer cells. These interactions are necessary for maintaining the CAF-phenotype, thereby unearthing a positive feedback loop between CAF-cancer cells interactions that sustain a tumor-permissive microenvironment [33]. 
Cancer invasion and metastasis is also closely associated with MMPs secreted by CAFs and tumor cells and increased MMP expression has been associated with poor prognosis for various cancers [34]. In addition to modifying the ECM, MMPs can facilitate tumor growth and invasion by increasing the bioavailability of ECM tethered growth factors. For instance, CAF-secreted matrix metalloproteinase-13 (MMP-13) enhanced tumor cells invasion through proteolytic cleavage of matrix-bound VEGF and angiogenesis [35].

An additional factor involved in CAF-tumor cell cross-talk is the fibroblast activation protein (FAP). FAP is exclusively expressed on activated fibroblasts, and increased expression is associated with poor prognosis in many tumors [36]. In OC, FAP promoted HO-8910PM tumor cell proliferation, invasion and migration via interactions with integrin $\alpha 3 \beta 1$ and urokinase-type plasminogen activator receptor (uPAR) signaling complex [37]. Moreover, elevated stromal FAP expression was a strong predictive marker of platinum resistance and relapse [38]. Due to the adverse effects of CAFs on cancer recurrence and patient survival, there has been extensive investment in developing strategies to effectively target CAFs.

\section{Therapies Targeting Fibroblasts}

FAP is overexpressed in many epithelial cancers including OC, and its expression is often associated with poor prognosis [36,38], cancer cell migration, invasion and immunosuppression [39-41]. As such, FAP has emerged as a potential therapeutic target to abate the tumor promoting effects of CAFs. The catalytic activity of FAP was shown to be necessary for tumor proliferation. However, inhibition of FAP enzymatic activity by small molecules has had little success in clinical trials [42,43]. In a transgenic mouse model, targeted depletion of FAP-expressing CAFs resulted in increased cancer cell death. Mechanistically, this effect was dependent on TNF- $\alpha$ and IFN- $\gamma$, which are known to be involved in $\mathrm{CD}^{+} \mathrm{T}$ cell mediated cancer cell death [41]. Furthermore, pre-clinical studies using vaccines against FAP showed promising results for colon and lung cancer. Vaccines targeting FAP-expressing cells significantly suppressed tumor growth by eliciting $\mathrm{CD} 8^{+}$or a combined $\mathrm{CD} 8^{+}$and $\mathrm{CD} 4^{+}-\mathrm{T}$ cell response respectively $[40,44]$.

TGF- $\beta$, a cytokine abundantly secreted by fibroblasts and detectable in ascites fluid, contributes to the development of a tumor-promoting microenvironment. Several TGF- $\beta$ targeting agents have been evaluated in clinical trials. These include small molecule kinase, antisense oligonucleotides, and TGF- $\beta$-ligand traps $[45,46]$. In a mouse model of peritoneal metastasis, the TGF- $\beta$ inhibitor A-83-01 improved overall survival $[47,48]$. Likewise, the transforming growth factor- $\beta$ receptor 1 (T $\beta$ RI) kinase inhibitor galunisertib inhibited tumor growth in a partly TME-dependent manner in various PDX tumors [49]. TGF- $\beta$ inhibitors have also been shown to enhance the efficacy of conventional therapeutics. For example, combination treatment with TGF- $\beta$ receptor inhibitor LY2109761 and cisplatin significantly blocked the growth of cisplatin-resistant ovarian xenografts [50]. Despite promising initial preclinical results, advancement of TGF- $\beta$ signaling inhibitors to the clinical arena has been slow, marred by initial concerns over systemic (cardiac) toxicity, which fortunately appears to be limited in humans [51].

Several other tyrosine kinase inhibitors (TKI) have been employed to mitigate the pro-tumorigenic effects of growth factors secreted by fibroblasts in the tumor milieu, such as the platelet derived growth factor (PDGF) and fibroblast growth factor (FGF). PDGF-D over-expression was associated with lymph node metastasis and platinum resistance in ovarian cancer [52] and imatinib, a PDGFR inhibitor, was shown to inhibit OC cell growth [53]. While the precise effects of imatinib on ovarian stroma are not well defined, previous research demonstrated that this TKI suppressed angiogenesis in cervical tumors [54]. Dasatinib, another FDA approved TKI, which also targets the PDGF receptor has been shown to partially revert lung cancer-derived CAFs to a normal phenotype [55]. Clinical trials tested the PDGFR inhibitors imatinib and sorafenib in patients with recurrent platinum resistant $O C$ and demonstrated modest clinical activity [56,57]. 


\section{Angiogenesis}

Angiogenesis is the process whereby new blood vessels sprout from the pre-existing vasculature. Angiogenesis is a tightly regulated and transient process observed in biological processes such as development, wound healing and reproduction [58]. However, pathological angiogenesis is a rate-limiting event in metastasis. As tumors increase in size $\left(>1-2 \mathrm{~mm}^{2}\right)$, nutrient and oxygen availability are reduced and an angiogenic switch is activated; the newly formed blood vessels are able to deliver nutrients and oxygen necessary for cancer cell proliferation, facilitate waste expulsion, and also provide the primary route by which cancer cells migrate to secondary sites (metastasis) [59]. In fact, tumor vascularity serves as an indicator of metastatic potential for many cancers with highly vascularized tumors having greater incidence of metastasis and reduced survival [60,61]. In cancers, angiogenesis is driven by reduced levels of anti-angiogenic factors, and sustained overproduction of pro-angiogenic molecules by tumor and host cells [58]. Angiogenesis is triggered by growth factors such as VEGF, PDGF, (FGF), angiopoietin (Ang), as well as the chemokines IL-8 and interleukin-6 (IL-6) $[59,62,63]$. The association between HGSOC and an angiogenic signature was recognized more than two decades ago and has remained a staple in the study of this tumor's biology. VEGF is the most extensively studied angiogenic factor in pathological angiogenesis; it is overexpressed in HGSOC and secreted into malignant ascites [64-67]. Increased VEGF expression is associated with reduced survival rates in patients with OC [68-70]. In a cohort of 222 HGSOC specimens, high levels of VEGF-A were correlated with increased microvessel density and with infiltration by immune cells [71]. Interestingly, high levels of VEGF-A were associated with BRCA-mutated ovarian tumors [71]. Although cancer cells are a major source of angiogenic factors, non-neoplastic cells (immune cells, adipocytes, and CAFs) in the TME also produce the angiogenic factors required to sustain tumor growth and progression [72]. As such, there has been considerable focus on developing therapeutics to inhibit the angiogenic signaling as a means of mitigating cancer progression.

\section{Anti-Angiogenic Therapy (AAT)}

VEGF is the most extensively studied pro-angiogenic factor and therapies targeting this pathway use either inhibition of the ligand or of its receptor, vascular endothelial growth factor receptor (VEGFR). VEGF-A is a secreted glycoprotein that belongs a family of related growth factors that includes VEGF-B, VEGF-C, VEGF-D and VEGF-E and placental growth factor (PLGF), which have varying functions in angiogenesis [73]. The VEGF system functions as a mitogenic factor for endothelial cells, induces endothelial cell migration and differentiation, and protects immature endothelial cell against apoptosis [74,75]. VEGF exerts these functions by binding to the tyrosine kinase receptors VEGFR-1 (Flt-1) and VEGFR-2 (KDR/Flk-1) on the cell surface, causing them to dimerize and become activated [76]. Bevacizumab (Avastin, Roche, Basel, Switzerland), is a humanized monoclonal antibody against VEGF that binds and inactivates VEGF, thus inhibiting endothelial cell activation and proliferation. Bevacizumab was shown to reduce tumor growth and prolong survival in murine ovarian cancer models $[77,78]$. Clinical trials using bevacizumab as a single agent and in combination with other therapeutics have been successful and bevacizumab is currently FDA approved for use in the front-line setting, as well as in recurrent disease $[79,80]$.

The first clinical trial to test the efficacy of bevacizumab in OC was performed by the Gynecologic Oncology Group (protocol GOG 170D) and tested the drug in 62 patients with recurrent, platinum-resistant disease. In this trial, $21 \%$ of patients exhibited objective clinical responses and $40.3 \%$ survived progression-free for at least 6 months. Median progression-free survival (PFS) and overall survival (OS) were 4.7 and 17 months respectively [81]. This initial success led to the development of combination therapies using bevacizumab with chemotherapy. In the ICON7 phase III trial, the efficacy of bevacizumab in combination with platinum and paclitaxel was tested in patients with advanced or metastatic epithelial ovarian cancer after cytoreductive surgery. Bevacizumab was continued for 12 additional cycles or until progression of disease. Progression-free survival at 42 months was increased from 22.4 months with chemotherapy alone to 24.1 months with combination 
treatment $(p=0.04)$. Interestingly, PFS and OS were most significantly increased in patients at high risk for progression. In this group, survival at 42 months was 28.8 months for patients receiving standard therapy vs. 36.6 months for patients receiving carboplatin/platinum and bevacizumab [82]. Similar results were observed in GOG protocol 218, where chemotherapy plus bevacizumab followed by bevacizumab maintenance improved PFS (but not OS) compared to platinum and paclitaxel alone after cytoreductive surgery [79]. In another randomized phase III clinical trial (AURELIA Trial), bevacizumab in combination with physician's choice chemotherapy was tested in women with recurrent platinum-resistant OC. The median PFS was 3.4 months for patients who received chemotherapy alone versus 6.7 months for patients treated with bevacizumab and chemotherapy [83]. These results summarized in Table 1 led to the approval and widespread clinical use of the first therapy targeting the ovarian cancer TME.

Table 1. Pivotal trials demonstrating Bevacizumab (Bev) clinical activity in OC.

\begin{tabular}{|c|c|c|c|c|c|c|c|}
\hline Study & $\begin{array}{l}\text { Course of } \\
\text { Treatment }\end{array}$ & Target & $\begin{array}{c}\text { TME } \\
\text { Component }\end{array}$ & $\begin{array}{c}\text { Patient } \\
\text { Population }\end{array}$ & $\begin{array}{c}\text { Phase } \\
\text { Trial Size }\end{array}$ & $\begin{array}{c}\text { Trial } \\
\text { Endpoint }\end{array}$ & $\begin{array}{l}\text { Clinical } \\
\text { Outcome }\end{array}$ \\
\hline ICON7 & Chemo \pm Bevac & VEGF-A & Endothelium & $\begin{array}{c}\text { High risk } \\
\text { ovarian cancer, } \\
\text { stage IIIC or IV }\end{array}$ & $\begin{array}{l}\text { Phase III N } \\
\quad=1528\end{array}$ & PFS & $\begin{array}{c}\text { At } 42 \text { months } \\
22.4 \text { vs. } 24.1 \\
\text { months } p=0.04\end{array}$ \\
\hline GOG218 & $\begin{array}{c}\text { Chemo vs. } \\
\text { Chemo + Bevac } \\
\text { initiation vs. } \\
\text { Chemo + Bevac } \\
\text { Throughout }\end{array}$ & VEGF-A & Endothelium & $\begin{array}{c}\text { New } \\
\text { Diagnosed } \\
\text { Stage III or IV } \\
\text { OC }\end{array}$ & $\begin{array}{l}\text { Phase III N } \\
\quad=1873\end{array}$ & PFS, OS & $\begin{array}{c}\text { Median PFS; } 10.3 \\
\text { vs. } 11.2 \text { vs. } 14.1 \\
\text { months; OS; } n s\end{array}$ \\
\hline AURELIA & Chemo \pm Bevac & VEGF-A & Endothelium & $\begin{array}{c}\text { Recurrent OC } \\
\text { PL-R }\end{array}$ & $\begin{array}{l}\text { Phase III N } \\
\quad=361\end{array}$ & PFS, OS & $\begin{array}{c}\text { Median PFS; } 3.4 \\
\text { vs. } 6.7 \text { months. } \\
\text { OS; } 13.3 \text { vs. } 16.6 \\
\text { months }\end{array}$ \\
\hline OCEANS & Chemo \pm Bevac & VEGF-A & Endothelium & $\begin{array}{l}\text { Recurrent OC } \\
\text { PL-S }\end{array}$ & $\begin{array}{l}\text { Phase III N } \\
\quad=484\end{array}$ & PFS & $\begin{array}{l}\text { Median PFS } 8.4 \\
\text { vs. } 12.4 \text { months }\end{array}$ \\
\hline GOG213 & Chemo \pm Bevac & VEGF-A & Endothelium & $\begin{array}{c}\text { Recurrent OC } \\
\text { PL-S }\end{array}$ & $\begin{array}{l}\text { Phase III N } \\
\quad=674\end{array}$ & ORR & $\begin{array}{c}\text { Median overall } \\
\text { survival } 37.3 \text { vs. } \\
42.2 \text { months }\end{array}$ \\
\hline
\end{tabular}

Other modalities to block this pathway are in development. For example, aflibercept is a recombinant fusion protein of VEGFR1 and VEGFR 2 extracellular domain, which functions as a decoy receptor and inhibits VEGF-mediated signaling by trapping VEGF-A, VEGF-B, placental growth factor-1 (PlGF-1) and (PIGF-2). Aflibercept was shown to reduce ascites and decrease the peritoneal dissemination of OC xenograft models [53,84-86]. A phase II trial tested the efficacy of aflibercept in patients with advanced platinum-resistant $O C$ and malignant ascites. Patients who required three or more previous paracenteses per month were given intravenous aflibercept $4 \mathrm{mg} / \mathrm{kg}$ every two weeks. The primary study endpoint was repeat paracentesis response rate (RPRR), and a response was defined as a minimum two-fold increase in time to repeat paracentesis compared with the baseline interval. Ten out of 16 patients treated achieved a response; RPRR was $62.5 \%$ (95\% CI 35.4-84.8\%). Median time to repeat paracentesis was 76.0 days (95\% CI 64.0-178.0), 4.5 times longer than the baseline (16.8 days) and the median PFS was 59.5 days (95\% CI 41.0-83.0) [87], demonstrating that targeting this growth factor in the TME leads to appreciable clinical benefits.

However, angiogenesis is a complex phenomenon tightly regulated by complementary and cross-talking pathways, which allows for the development of resistance [88]. Thus, inhibitors that concurrently block multiple receptors were tested in an effort to improve the efficacy of AAT. Cediranib (AZD2171, AstraZeneca) is a receptor tyrosine kinase inhibitor that inhibits vascular endothelial receptor 1-3 (VEGFR 1-3), platelet-derived growth factor- $\alpha$ and $\beta$ (PDGFR- $\alpha$ and $-\beta$ ), and c-kit. A phase II clinical trial assessed the efficacy of cediranib in patients with recurrent gynecologic cancers who had received less than two lines of platinum-based chemotherapy. Of 46 patients treated, eight patients $(17 \%)$ had partial responses (PR), six patients (13\%) stable disease (SD), and there were 
no complete responses (CRs) [89]. In another phase II trial, the efficacy of single-agent cediranib was assessed in 74 patients with persistent/recurrent OC following one round of platinum-based chemotherapy. The patients were stratified into two groups; 39 platinum-sensitive (PL-S) and 35 platinum-resistant (PL-R), and the primary endpoint was objective response rate at 16 weeks. In the platinum sensitive (PL-S) group, 10 patients (26\%) demonstrated partial responses (PR) and 20 $(51 \%)$ had stable disease (SD). There were no confirmed PR in the platinum resistant (PL-R) group and 23 patients $(66 \%)$ had SD. The median PFS was 7.2 months for PL-S and 3.7 months for PL-R groups, and the median OS was 27.7 and 11.9 months respectively [90]. Currently cediranib is being evaluated in combination with olaparib, a poly (ADP-ribose) polymerase PARP inhibitor in women with recurrent OC.

Nintedanib is another tyrosine kinase inhibitor for VEGFR-1-3, FGFR 1-3, PDGFR $\alpha$ and $\beta$. Nintedanib was tested as maintenance treatment after chemotherapy in a randomized trial. PFS at $36-$ weeks was $5.0 \%$ vs. $16.3 \%$ in placebo and nintedanib treated patients [91]. However, in a subsequent phase III trial (AGO-OVAR 12) nintedanib combined with platinum-based therapy did not induce a significant survival advantage after debulking surgery. The median PFS was 17.2 vs. 16.6 months for patients treated with nintedanib and placebo, respectively. A post-hoc analysis showed that nintedanib and platinum-based therapy combination improved PFS in non-high-risk patients [92]. Pazopanib (GW786034) is tyrosine kinase inhibitor for VEGFR-1, -2 and -3 PDGFR- $\alpha$ and $-\beta$ and c-kit. An ongoing clinical phase II trial (MITO-11) is evaluating the safety and activity of pazopanib in combination with paclitaxel in patients with platinum-resistant or refractory OC. The median progression-free survival was 3.5 months in patients treated with weekly paclitaxel vs. 6.3 months in patients treated with weekly paclitaxel and pazopanib. The median overall survival was 14.8 months in paclitaxel treated vs. 18.7 months in patients treated with paclitaxel and pazopanib [93]. In all, these and other trials have convincingly demonstrated the activity of AAT in HGSOC, leading to the approval of bevacizumab for treatment in both the adjuvant and recurrent settings. New trials are evaluating the efficacy of anti-angiogenic drugs in combination with immune modulators or PARP inhibitors for treatment of gynecologic malignancies.

\section{Interactions with the Mesothelial Matrix}

In order to form secondary tumors, disseminated OC cell spheroids floating in the peritoneal cavity rely on their capacity to adhere to the mesothelial lining covering the peritoneal cavity and abdominal organs. During dissemination from the primary site, OC cells lose E-cadherin expression (Figure 2, upper left) and upregulate $\alpha 5$ integrin, which was proposed as a therapeutic target [94]. Secondary site invasion occurs upon displacement of the mesothelial monolayer cells (Figure 2, lower right), with cancer cells invading and submerging into the subjacent environment. The clearance of mesothelial cells is enabled by traction forces mediated by myosin and generated by the adhesion complex molecules, $\alpha 5$ integrin and talin-1, and is more efficiently accomplished by reprogrammed mesenchymal-like OC cells $[95,96]$. Other receptors that play a role in OC cell adhesion to mesothelium include CD44 and $\beta 1$ integrin (I $\beta 1$ ) [97]. OC cell-derived TGF- $\beta 1$ upregulates fibronectin (FN) expression in mesotheial cells [98]. The adhesion of OC cells to the FN matrix secreted by mesothelial cells [98] is dependent upon $\alpha 5 \beta 1$ integrin clustering and talin recruitment to stabilize the adhesions (Figure 2) [95]. Integrin clustering is induced by secreted tissue transglutaminase (TG2), which forms a bridge connecting $I \beta 1$ and FN together at the cell surface [99]. This event induces downstream RhoA activation and suppression of Src-p190RhoGAP signaling. A focus of our laboratory's work was to understand the role played by the TG2-I $\beta 1-F N$ ternary complex in the process of OC metastasis and to test it as a new therapeutic target. By using OC orthotopic and ip xenografts, we showed that TG2 knock-down blocked peritoneal dissemination of ovarian tumors through a mechanism dependent on $\beta 1$-integrin mediated cell adhesion and signaling $[100,101]$. Our recent results also demonstrate that engagement of integrin $\beta 1$ facilitated by TG2 activates $\beta$-catenin signaling and stemness associated pathways in in vivo and organoid models of HGSOC [102,103]. 

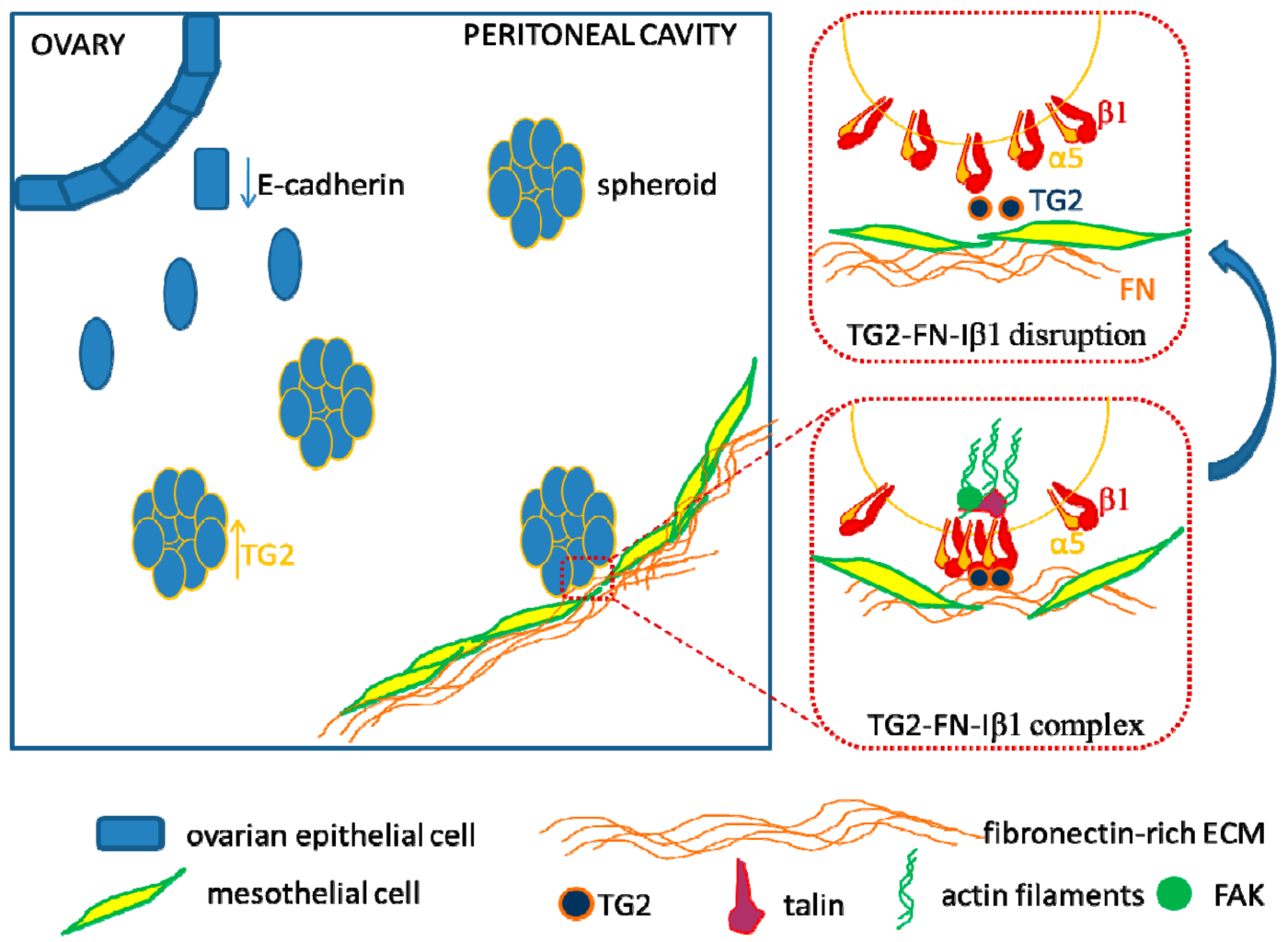

Figure 2. Ovarian cancer cells adhere to the mesothelial lining during tumor dissemination in the peritoneal cavity. Upon activation of EMT (epithelial-to-mesenchymal transition), cells progressively shed from the primary tumor into the peritoneal cavity (blue square). During the EMT process, there is a decrease in E-cadherin expression and increase in proteins associated to a mesenchymal phenotype, such as vimentin, tissue transglutaminase (TG2) and integrins. Cells that survive in the environment of the peritoneal cavity form spheroids. Spheroids attach to the fibronectin (FN) rich matrix secreted by the mesothelial cells, clear the subjacent monolayer and invade the underling tissue. These adhesion and invasion processes are mediated by interactions of integrin- $\beta 1$ receptors with the FN fibrils in the ECM. Upon FN binding, $\alpha 5 \beta 1$ integrin receptors undergo clustering, which is enhanced by molecular bridges with TG2. Next, talin is recruited to the adhesion complex and provides the necessary traction force for the mesothelial monolayer displacement (red dotted bottom square). Also, "outside-in" signaling downstream of $\beta 1$ integrin is activated, inducing focal adhesion kinase (FAK) phosphorylation. Therapeutic strategies targeting the TG2-FN-I $\beta 1$ complex aim at interfering with the cell adhesion process and consequently preventing OC metastasis (red dotted top square).

\section{Targeting Ovarian Cancer Cell Adhesion to the Peritoneal Matrix}

Several strategies have been tested in an effort to block OC peritoneal dissemination. Treatment with blocking antibodies against integrins and the CD44 receptor were shown to inhibit OC cells adhesion to the mesothelial layer for short time intervals [104-106]. As $\alpha 5 \beta 1$ integrin is expressed on both OC cells as well as on the endothelial cells forming microvessels [107], it was expected that targeting this heterodimer (Figure 2, top square) will interfere with tumor growth and metastasis in many types of solid cancers, including OC [108]. Currently several drugs targeting integrins are under development (reviewed in [109]).

Volociximab, a chimeric antibody that binds $\alpha 5 \beta 1$ integrin with high affinity, was shown to block growth and dissemination of OC xenograft models [94]. However, the phase II clinical trial testing volociximab in patients with recurrent, platinum-resistant $\mathrm{OC}$ failed to demonstrate benefit although the drug was well tolerated [110]. Intetumumab (CNTO-95), a human $\alpha$ v-integrin specific monoclonal antibody that targets both $\alpha v \beta 3$ - and $\alpha v \beta 5$-integrins showed anti-tumor and 
anti-angiogenic effects in xenografts models of breast cancer [111,112]. In a phase I clinical trial including patients with advanced solid tumors, one patient with ovarian carcinosarcoma had stable disease for six months [113]. Other integrin-blocking antibodies, such as etaracizumab, the humanized version of anti- $\alpha \mathrm{v} \beta 3$-integrin LM609 had minimal therapeutic benefit in other cancers [114]. Cilengitide is a stable cyclic pentapeptide containing an Arg-Gly-Asp (RGD) motif which allows selective binding to $\alpha v \beta 3$ and $\alpha \mathrm{v} \beta 5$ integrins [115]. Cilengitide was tested in brain tumors and was found to not increase OS in glioblastoma patients during a phase III trial [116]. Given that $\alpha v \beta 3$ integrin expression by tumor cells correlates with a favorable prognosis in OC patients [117], targeting this integrin might be a less appropriate strategy for OC. The initial disappointment with integrin targeting strategies may be related to their prior testing in the recurrent, advanced setting as single agents. Development of combination regimens and testing of these blocking antibodies in patients with low volume metastatic disease might overcome the lack of clinical success with this intervention.

FN is one of the most abundant ECM proteins in the omentum and peritoneum [118]. Adhesion of OC cells to FN via $\alpha 5 \beta 1$ integrin impacts "outside-in signaling" by inducing phosphorylation of focal adhesion kinase (FAK) either directly [119] or through c-Met [108]. This can further lead to activation of mitogenic pathways [120] which support tumor growth [121]. The $\beta 1$ integrin-FN interaction is further enhanced by the bridging activity of TG2, a protein we discovered to be overexpressed in OC [122]. Previous work in our group has emphasized the importance of TG2 in the OC metastatic process, by providing evidence of its involvement in promoting OC cells' epithelial-to-mesenchymal transition through activation of non-canonical NF- $\mathrm{KB}$ [123], increasing cell proliferation by regulating $\beta$-catenin signaling [102], enhancing peritoneal dissemination [100], and increasing invasion by regulating MMP-2 [124]. As proof of principle that the TG2-FN-I $\beta 1$ complex represents an interesting target in OC, we used a function-blocking antibody which targeted the FN binding domain of TG2, and showed that this antibody blocked OC spheroid proliferation and tumor initiating capacity by disrupting the interaction between OC stem cells and their niche [103].

To discover potent and selective TG2-FN inhibitors we used both virtual docking and high throughput screening strategies. Through an initial in silico docking approach, we identified a small molecule inhibitor capable of disrupting this complex and of blocking cancer cell adhesion to the FN matrix [125]. Subsequent efforts used an AlphaLISA-based assay adapted to high-throughput screening and applied to the ChemDiv library leading to the discovery and validation of several small molecules [126]. One hit selected from this screen (TG53) was validated in vitro to be an efficient inhibitor of OC cell adhesion to FN, migration and invasion. Future efforts focus on optimizing this compound through structure-activity relationship-based strategies to generate more selective, potent and drug-like compounds which block the TG2-FN protein-protein interaction and ultimately prevent OC metastasis.

\section{Tumor Immune Response in Ovarian Cancer}

Preclinical models and retrospective cohort analyses of human tumor specimens have demonstrated that the interaction between cancer cells and the host immune defense plays an important role harnessing tumor progression. There are several immune cell subsets relevant for tumor progression and response to immunotherapy [127]. These are classified in two categories: immune reactive and immune suppressive cells. The immune reactive cells include primarily cytotoxic $\mathrm{T}$ lymphocytes and activated $\mathrm{CD}^{+} \mathrm{T}$ cells. The immune suppressive cells are myeloid lineage subpopulations known as myeloid-derived suppressor cells (MDSCs), tumor-associated macrophages (TAMs, especially M2 subtype), dendritic cells (DCs) and the lymphocyte subsets of Thelper cells (Th2 subtype) and T regulatory cells (Tregs). A seminal study showed that the presence of $\mathrm{CD}^{+}$tumor infiltrating lymphocytes (TILs) in OC is associated with increased survival [128]. The 5-year overall survival (OS) was $38 \%$ for patients whose tumors contained T cells compared to $4.5 \%$ for those whose tumors were devoid of T cells. Subsequently, a strong association between the presence of CD8 ${ }^{+} \mathrm{TILs}$ and favorable clinical outcomes of HGSOC was recognized [129-131]. The CD8 ${ }^{+}$to T regulatory (Tregs) 
cells ratio was also shown to correlate with increased survival of OC patients [130]. More recently, the presence of $\mathrm{CD}^{+}$cells expressing the TNFR-family receptor CD137 (4-1BB) was reported as a prognostic marker associated with improved survival of OC patients [132]. A recent study evaluated the immune TME landscape in differentially growing metastases after several therapy cycles in an OC patient and reported heterogeneity in immune infiltrates that explained the evolution of tumor masses over nine years period [133]. This unique report revealed a correlation between the regressing or stable metastases and the presence of oligoclonal expanding $\mathrm{T}$ cells. Conversely, progressing tumors showed a lack of infiltration with anti-cancer lymphocytes. This study reinforces the importance of the tumor immune microenvironment to the outcome of OC disease. In all, these and other studies [134] strongly support the role of anti-tumor immunity as a key regulator in the evolution of the disease.

Enhancing the naturally occurring immune defense could therefore play an important role harnessing disease progression. Immunotherapy has demonstrated efficacy in various malignancies [135,136]. Several immune modulatory approaches (vaccines, IL2, CTLA-4 directed antibodies, adoptive transfer of activated T cells) have been tested in OC, with promising results in early interventions $[137,138]$. However, the impact of immunotherapy on the survival of OC patients remains unproven and predictive markers of positive outcomes remain undefined, highlighting the need to further optimize such strategies.

\section{Immune Checkpoint Inhibitors}

Recent advances have brought attention to the programmed cell death protein-1 (PD-1) mechanism used by cancer cells to evade immune surveillance, which can be effectively targeted by inhibitory antibodies [139]. This strategy demonstrated impressive clinical activity in several solid tumors (melanoma, lymphoma, renal, lung, and bladder cancer) leading to new FDA-approved interventions [140-142]. PD-1 signaling blocks T-cell activation keeping nascent T-cells in check and preventing immune responses against normal tissues. During cancer progression, this inhibitory pathway is activated by upregulating the expression of PD ligands (PD-L1 and PD-L2) on tumor and immune cells and permits evasion from immune surveillance [139]. The significance of the PD1 pathway to OC progression has been investigated; however, the emerging evidence is conflicting. On one hand, initial studies showed that the increased PD-L1 expression in ovarian tumors correlates with decreased intra-tumoral CD8 ${ }^{+}$lymphocytes and worse patient survival [143]. Presence of dendritic cells expressing PD1 in the OC microenvironment was also found to be associated with decreased numbers of TILs and suppressed T cell activity [144], consistent with the concept that PD-L1 represents an escape mechanism. On the other hand, more recent studies using specific PD1 and PD-L1 detection antibodies provide evidence to the contrary. Two reports showed that expression of PD-L1 on immune cells in the tumor milieu, including on tumor associated macrophages (TAMs), is associated with increased total numbers of TILs and better survival in HGSOC [145,146]. It remains unresolved how expression of the PD1 pathway elements can be causally linked to a favorable prognosis in OC. It is possible that expression of PD-L1 reflects an active immune TME (defined by increased TILs density) able to attack and eliminate the tumor, or that PD-L1 ${ }^{+}$TILs have a yet to be defined regulatory role in the immune response mechanism. Additional support for clinical interventions targeting this pathway includes that PD-1/PD-L1 blockade restored anti-tumor immunity in an OC xenograft model [147]. Two recent clinical trials tested PD-1 (pembrolizumab) and PD-L1 (avelumab) inhibitory antibodies in women with recurrent OC, reporting response rates of 11\% (pembrolizumab) and 10\% (avelumab), with $23 \%$ and $40 \%$ additional patients experiencing stable disease, respectively [148,149]. These early data suggest that immune checkpoint blockade in OC has defined, albeit modest activity.

Another emerging concept refers to the tumor neoantigen load as an important regulator of anti-tumor immune response and a marker for response to treatment [150,151]. Along these lines, a recent study showed that BRCA 1 and 2 mutated ovarian tumors are characterized by increased neoantigen load and that this correlates with increased number of TILs, increased expression of PD1 and PDL1, and is linked to improved clinical outcome [152]. These data support exploring 
PD1 blockade in OC and continued investigation of the complex immune milieu associated with ovarian tumors. Therefore, identifying rational combinations to enhance the activity of PD1 blocking antibodies in OC and further analysis of the immune tumor milieu to identify predictive markers is necessary. Our group is exploring the combination of the PD1 inhibitor pembrolizumab and the DNA hypomethylating agent guadecitabine in women with recurrent platinum-resistant ovarian cancer (NCT02901899), testing the hypothesis that epigenomic priming will enhance the activity of immune checkpoint inhibitors.

\section{Targeting Tumor Associated Macrophages (TAMs) and Myeloid-Derived Suppressor Cells (MDSCs)}

Myeloid cells are frequently observed in the stroma of growing tumors [153]. The role of myeloid suppressor cells has been recognized first in late 1970s. In 2007, the term myeloid-derived suppressor cells (MDSCs) was coined for "bone marrow-derived cells of myeloid lineage comprising myeloid precursors and immature macrophages, granulocytes, and DCs, characterized by their high potential to suppress T cells" [154]. Immature myeloid suppressor cells were shown even earlier to accumulate in a variety of immune-related diseases, including cancer $[155,156]$. MDSC subsets were found to be responsible for immune suppression in 10 pre-clinical models of tumorigenesis [157]. In OC, macrophages are mainly found in ascites or infiltrate of the omentum. TAMs in the omentum were shown to harbor predominantly the M2 phenotype and to facilitate tumor progression $[158,159]$. Peritoneal TAMs support this process by secreting cytokines such as IL-6 and IL-8 [160]. In the ascites, M2 macrophage-like TAMs were found in the center of spheroids, where they participated in mechanisms supporting tumor cell proliferation and migration during OC metastasis [161]. The main signaling pathway involved in TAMs cross-talk to floating spheroid cancer cells was EGF-EGFR. TAMs promoted cancer cell invasiveness by activating the NF-KB and JNK signaling pathways [162]. Reversely, peritoneal macrophages were shown to adopt the M2 phenotype under the influence of OC cells expressing homeobox gene HOXA9 [163]. PD-L1 was primarily expressed by CD68 ${ }^{+}$TAMs rather than tumor cells in HGSOC, and often colocalized with both cytotoxic $\mathrm{T}$ cells as well as T regulatory cells and was a positive prognostic marker [146].

The contribution of MDSCs defined as harboring $\mathrm{Lin}^{-} \mathrm{CD} 45^{+} \mathrm{CD} 33^{+}$markers combination was studied in a cohort of patients with HGSOC [164]. MDSC s comprised 37\% of non-neoplastic cells in the TME and were responsible for inhibiting T-cell immunity, by blocking both T cell proliferation and effector function. Increased tumor MDSCs inversely correlated with CD8 $8^{+}$TILs and overall survival in advanced OC [165]. Interestingly, the corresponding $\mathrm{Lin}^{-} \mathrm{CD} 45^{+} \mathrm{CD} 33^{+}$fraction in patients blood did not have the same properties. MDSCs were shown to support metastasis and a cancer stem cell phenotype. Mechanistically, it was shown that tumor-resident MDSCs enhance stemness via microRNA101, which targets co-repressor gene C-terminal binding protein-2 (CtBP2) 3'-UTR region and interferes with its binding at NANOG, OCT4/3, and SOX2 promoters in primary OC cells [164]. Primary ovarian tumors expressing high levels of Snail were shown to recruit increased number of CD33 ${ }^{+}$MDSCs through secretion of the CXCR2 ligands CXCL1/2 [166,167]. Therefore, blocking CXCR2 would represent a therapeutic approach for Snail-high OC tumors.

Targeting immature myeloid cells and their cross-talk with other immune cells and cancer cells is a potential strategy of combating tumor progression. Several classes of therapeutics targeting MDSCs or TAMs have been described and were recently reviewed [167]. They include agents which promote MDSCs apoptosis, antibodies that induce MDSCs and/or TAMs depletion, compounds that induce immature myeloid cells differentiation (such as retinoic acid, vitamin D3 or HDACi), inhibitors of immune suppression function (sildenafil, triterpenoids, inhibitors of COX-2, inducible nitric oxide), compounds which block recruitment (by targeting chemokines and chemokine receptors) or MDSCs proliferation, and lastly TAM reprogramming factors. Given that TAMs and MDSCs mediate resistance to immunotherapy targeting, this immune suppressive cell population could increase the success rate of checkpoint blockade inhibitors [168]. 
Several strategies have been tested in preclinical models, but progress towards clinical is still ongoing. For example, almetuzumab, which targets CD52 expressed by vascular leukocytes and $\mathrm{Tie}^{+}$monocytes, was shown to have anti-myeloid and anti-angiogenic properties in OC models [169]. Anti-CD52 therapy decreased tumor growth in an OC murine model. Additionally, ovarian TAMs express high levels of folate receptor-2, which can be targeted by using methotrexate loaded G5-dendrimers (G5-MTX) [170]. Noteworthy, these G5-MTX nanoparticles were shown to overcome resistance to anti-VEGF-A therapy in OC preclinical models. Epigenetic modulators have also been shown to alter the myeloid population, triggering anti-tumor immune responses. For example, the bromodomain inhibitor JQ1 significantly reduced PD-L1 expression on TAMs and dendritic cells, induced increased $\mathrm{T}$ cell cytotoxic activity and suppressed $\mathrm{OC}$ tumor growth in preclinical models [171]. A combination of histone deacetylase inhibitors (HDACi) and DNA methyltransferase inhibitor (DNMTi) was shown to reduce TAMs and increase T and NK cell activation, delaying tumor progression in preclinical models [172]. The combination of DNMTi/HDACi also synergized with the immune checkpoint inhibitors. Clinical trials testing HDACi and DNMTi with anti-PD1 therapy in patients with recurrent $\mathrm{OC}$ are ongoing. Lastly, catumaxomab is a humanized antibody that targets three different cell types: tumor cells (via epithelial cell adhesion molecule (EpCAM) binding); T-cells (via CD3 binding); and accessory cells (macrophages, dendritic cells, and natural killer cells) via type I, IIa, and III Fc $\gamma$ receptors (Fc $\gamma$ R). Subsequently, catumaxomab induces several effects, including T-cell-mediated tumor lysis, antibody-dependent cell-mediated cytotoxicity, and phagocytosis via activation of NK cells and TAMs. Catumaxomab is administered intra-peritoneally and was shown to be clinically active in patients with malignant ascites, leading to its approval in Europe for the treatment of $\mathrm{EpCAM}^{+}$tumors associated with ascites, including HGSOC [173].

\section{Conclusions}

New targets at the interface between HGSOC cells and the TME have been characterized. Targeted treatments, alone or in combination with chemotherapy, are emerging and, in some situations, are already impacting clinical outcomes in women with HGSOC. Anti-angiogenic therapy in combination with chemotherapy has significantly improved the survival of women with advanced OC and has become part of the standard approach. In contrast, CAFs-directed strategies or therapeutics targeting cell adhesion to the matrix remain less impressive. Future development of combination and sequencing strategies based on a refined understanding of tumor biology and cross-talking pathways is critically needed. While immune interventions are still being optimized, early results suggest that combination strategies are needed to overcome the immune tolerant milieu of HGSOC. This could be due to silencing of tumor antigen and low tumor mutational burden, which render the ovarian tumors to be "cold", or to an infiltration of immunosuppressive cells. Therefore, current approaches investigate dual immune targeting or combinations with interventions that de-repress tumor antigens through epigenetic reprogramming or which increase the tumor mutational burden by inducing DNA damage. It is clear that in order to improve clinical outcomes in this fatal malignancy, interventions affecting both cancer cells and the stroma need to be implemented. Thus, we anticipate that clinical trials will continue to explore rationally designed combinations and/or sequences of therapies targeting vulnerabilities of both tumor cells and the TME.

Funding: This research was supported through funding from US Department of Veterans' Affairs, BX000792-06 and the Department of Defense W81XWH-17-1-0141 (to Daniela Matei), and the National Cancer Institute Training Grant T32 CA070085 (to Nkechiyere G. Nwani).

Conflicts of Interest: D.M. received consulting honoraria from Roche. The other authors declare no conflict of interest. The funders had no role in the design of the study; in the collection, analyses, or interpretation of data; in the writing of the manuscript, and in the decision to publish the results. 


\section{References}

1. Freedman, R.S.; Deavers, M.; Liu, J.; Wang, E. Peritoneal inflammation-A microenvironment for epithelial ovarian cancer (eoc). J. Transl. Med. 2004, 2, 23. [CrossRef] [PubMed]

2. Said, N.; Socha, M.J.; Olearczyk, J.J.; Elmarakby, A.A.; Imig, J.D.; Motamed, K. Normalization of the ovarian cancer microenvironment by sparc. Mol. Cancer Res. 2007, 5, 1015-1030. [CrossRef] [PubMed]

3. Hurteau, J.; Rodriguez, G.C.; Whitaker, R.S.; Shah, S.; Mills, G.; Bast, R.C.; Berchuck, A. Transforming growth factor-beta inhibits proliferation of human ovarian cancer cells obtained from ascites. Cancer 1994, 74, $93-99$. [CrossRef]

4. Gopinathan, G.; Milagre, C.; Pearce, O.M.; Reynolds, L.E.; Hodivala-Dilke, K.; Leinster, D.A.; Zhong, H.; Hollingsworth, R.E.; Thompson, R.; Whiteford, J.R.; et al. Interleukin-6 stimulates defective angiogenesis. Cancer Res. 2015, 75, 3098-3107. [CrossRef] [PubMed]

5. Nozawa, H.; Chiu, C.; Hanahan, D. Infiltrating neutrophils mediate the initial angiogenic switch in a mouse model of multistage carcinogenesis. Proc. Natl. Acad. Sci. USA 2006, 103, 12493-12498. [CrossRef] [PubMed]

6. Nieman, K.M.; Kenny, H.A.; Penicka, C.V.; Ladanyi, A.; Buell-Gutbrod, R.; Zillhardt, M.R.; Romero, I.L.; Carey, M.S.; Mills, G.B.; Hotamisligil, G.S.; et al. Adipocytes promote ovarian cancer metastasis and provide energy for rapid tumor growth. Nat. Med. 2011, 17, 1498-1503. [CrossRef] [PubMed]

7. Tarin, D.; Croft, C.B. Ultrastructural features of wound healing in mouse skin. J. Anat. 1969, 105, $189-190$. [PubMed]

8. Chang, H.Y.; Chi, J.T.; Dudoit, S.; Bondre, C.; van de Rijn, M.; Botstein, D.; Brown, P.O. Diversity, topographic differentiation, and positional memory in human fibroblasts. Proc. Natl. Acad. Sci. USA 2002, 99, 12877-12882. [CrossRef] [PubMed]

9. McAnulty, R.J. Fibroblasts and myofibroblasts: Their source, function and role in disease. Int. J. Biochem. Cell Biol. 2007, 39, 666-671. [CrossRef] [PubMed]

10. Ryan, G.B.; Cliff, W.J.; Gabbiani, G.; Irle, C.; Montandon, D.; Statkov, P.R.; Majno, G. Myofibroblasts in human granulation tissue. Hum. Pathol. 1974, 5, 55-67. [CrossRef]

11. Kalluri, R.; Zeisberg, M. Fibroblasts in cancer. Nat. Rev. Cancer 2006, 6, 392-401. [CrossRef] [PubMed]

12. Bhowmick, N.A.; Chytil, A.; Plieth, D.; Gorska, A.E.; Dumont, N.; Shappell, S.; Washington, M.K.; Neilson, E.G.; Moses, H.L. Tgf-beta signaling in fibroblasts modulates the oncogenic potential of adjacent epithelia. Science 2004, 303, 848-851. [CrossRef] [PubMed]

13. Liao, D.; Luo, Y.; Markowitz, D.; Xiang, R.; Reisfeld, R.A. Cancer associated fibroblasts promote tumor growth and metastasis by modulating the tumor immune microenvironment in a $4 \mathrm{t} 1$ murine breast cancer model. PLoS ONE 2009, 4, e7965. [CrossRef] [PubMed]

14. Kendall, R.T.; Feghali-Bostwick, C.A. Fibroblasts in fibrosis: Novel roles and mediators. Front. Pharmacol. 2014, 5, 123. [CrossRef] [PubMed]

15. Hanahan, D.; Coussens, L.M. Accessories to the crime: Functions of cells recruited to the tumor microenvironment. Cancer Cell 2012, 21, 309-322. [CrossRef] [PubMed]

16. Madar, S.; Goldstein, I.; Rotter, V. 'Cancer associated fibroblasts'-More than meets the eye. Trends Mol. Med. 2013, 19, 447-453. [CrossRef] [PubMed]

17. Giusti, I.; Francesco, M.D.; Ascenzo, S.; Palmerini, M.G.; Macchiarelli, G.; Carta, G.; Dolo, V. Ovarian cancer-derived extracellular vesicles affect normal human fibroblast behavior. Cancer Biol. Ther. 2018, 19, 722-734. [CrossRef] [PubMed]

18. Yao, Q.; Qu, X.; Yang, Q.; Wei, M.; Kong, B. Clic4 mediates tgf-beta1-induced fibroblast-to-myofibroblast transdifferentiation in ovarian cancer. Oncol. Rep. 2009, 22, 541-548. [PubMed]

19. Fang, T.; Lv, H.; Lv, G.; Li, T.; Wang, C.; Han, Q.; Yu, L.; Su, B.; Guo, L.; Huang, S.; et al. Tumor-derived exosomal mir-1247-3p induces cancer-associated fibroblast activation to foster lung metastasis of liver cancer. Nat. Commun. 2018, 9, 191. [CrossRef] [PubMed]

20. Jeon, E.S.; Moon, H.J.; Lee, M.J.; Song, H.Y.; Kim, Y.M.; Cho, M.; Suh, D.S.; Yoon, M.S.; Chang, C.L.; Jung, J.S.; et al. Cancer-derived lysophosphatidic acid stimulates differentiation of human mesenchymal stem cells to myofibroblast-like cells. Stem Cells 2008, 26, 789-797. [CrossRef] [PubMed]

21. Ko, S.Y.; Barengo, N.; Ladanyi, A.; Lee, J.S.; Marini, F.; Lengyel, E.; Naora, H. Hoxa9 promotes ovarian cancer growth by stimulating cancer-associated fibroblasts. J. Clin. Investig. 2012, 122, 3603-3617. [CrossRef] [PubMed] 
22. Dotto, G.P.; Weinberg, R.A.; Ariza, A. Malignant transformation of mouse primary keratinocytes by harvey sarcoma virus and its modulation by surrounding normal cells. Proc. Natl. Acad. Sci. USA 1988, 85, 6389-6393. [CrossRef] [PubMed]

23. Ozdemir, B.C.; Pentcheva-Hoang, T.; Carstens, J.L.; Zheng, X.F.; Wu, C.C.; Simpson, T.R.; Laklai, H.; Sugimoto, H.; Kahlert, C.; Novitskiy, S.V.; et al. Depletion of carcinoma-associated fibroblasts and fibrosis induces immunosuppression and accelerates pancreas cancer with reduced survival. Cancer Cell 2014, 25, 719-734. [CrossRef] [PubMed]

24. Cornil, I.; Theodorescu, D.; Man, S.; Herlyn, M.; Jambrosic, J.; Kerbel, R.S. Fibroblast cell-interactions with human-melanoma cells affect tumor-cell growth as a function of tumor progression. Proc. Natl. Acad. Sci. USA 1991, 88, 6028-6032. [CrossRef] [PubMed]

25. Givel, A.M.; Kieffer, Y.; Scholer-Dahirel, A.; Sirven, P.; Cardon, M.; Pelon, F.; Magagna, I.; Gentric, G.; Costa, A.; Bonneau, C.; et al. Mir200-regulated cxcl12beta promotes fibroblast heterogeneity and immunosuppression in ovarian cancers. Nat. Commun. 2018, 9, 1056. [CrossRef] [PubMed]

26. Wei, D.; Geng, F.; Liang, S.; Zhao, H.; Liu, M.; Wang, H. Caf-derived hgf promotes cell proliferation and drug resistance by up-regulating the c-met/pi3k/akt and grp78 signalling in ovarian cancer cells. Biosci. Rep. 2017, 37, BSR20160470.

27. Cirri, P.; Chiarugi, P. Cancer associated fibroblasts: The dark side of the coin. Am. J. Cancer Res. 2011, 1, 482-497. [PubMed]

28. Henriksson, M.L.; Edin, S.; Dahlin, A.M.; Oldenborg, P.A.; Oberg, A.; Van Guelpen, B.; Rutegard, J.; Stenling, R.; Palmqvist, R. Colorectal cancer cells activate adjacent fibroblasts resulting in fgf1/fgfr3 signaling and increased invasion. Am. J. Pathol. 2011, 178, 1387-1394. [CrossRef] [PubMed]

29. Matsuo, Y.; Ochi, N.; Sawai, H.; Yasuda, A.; Takahashi, H.; Funahashi, H.; Takeyama, H.; Tong, Z.; Guha, S. Cxcl8/il-8 and cxcl12/sdf-1alpha co-operatively promote invasiveness and angiogenesis in pancreatic cancer. Int. J. Cancer 2009, 124, 853-861. [CrossRef] [PubMed]

30. Orimo, A.; Gupta, P.B.; Sgroi, D.C.; Arenzana-Seisdedos, F.; Delaunay, T.; Naeem, R.; Carey, V.J.; Richardson, A.L.; Weinberg, R.A. Stromal fibroblasts present in invasive human breast carcinomas promote tumor growth and angiogenesis through elevated sdf-1/cxcl12 secretion. Cell 2005, 121, 335-348. [CrossRef] [PubMed]

31. Lau, T.S.; Chan, L.K.; Wong, E.C.; Hui, C.W.; Sneddon, K.; Cheung, T.H.; Yim, S.F.; Lee, J.H.; Yeung, C.S.; Chung, T.K.; et al. A loop of cancer-stroma-cancer interaction promotes peritoneal metastasis of ovarian cancer via tnfalpha-tgfalpha-egfr. Oncogene 2017, 36, 3576-3587. [CrossRef] [PubMed]

32. Mitchell, M.I.; Engelbrecht, A.M. Metabolic hijacking: A survival strategy cancer cells exploit? Crit. Rev. Oncol. Hematol. 2017, 109, 1-8. [CrossRef] [PubMed]

33. Zhao, L.J.; Ji, G.L.; Le, X.B.; Wang, C.; Xu, L.; Feng, M.; Zhang, Y.G.; Yang, H.L.; Xuan, Y.; Yang, Y.F.; et al. Long noncoding rna linc00092 acts in cancer-associated fibroblasts to drive glycolysis and progression of ovarian cancer. Cancer Res. 2017, 77, 1369-1382. [CrossRef] [PubMed]

34. Hadler-Olsen, E.; Winberg, J.O.; Uhlin-Hansen, L. Matrix metalloproteinases in cancer: Their value as diagnostic and prognostic markers and therapeutic targets. Tumor Biol. 2013, 34, 2041-2051. [CrossRef] [PubMed]

35. Lederle, W.; Hartenstein, B.; Meides, A.; Kunzelmann, H.; Werb, Z.; Angel, P.; Mueller, M.M. Mmp13 as a stromal mediator in controlling persistent angiogenesis in skin carcinoma. Carcinogenesis 2010, 31, 1175-1184. [CrossRef] [PubMed]

36. Garinchesa, P.; Old, L.J.; Rettig, W.J. Cell-surface glycoprotein of reactive stromal fibroblasts as a potential antibody target in human epithelial cancers. Proc. Natl. Acad. Sci. USA 1990, 87, 7235-7239. [CrossRef]

37. Yang, W.; Han, W.; Ye, S.; Liu, D.; Wu, J.; Liu, H.; Li, C.; Chen, H. Fibroblast activation protein-alpha promotes ovarian cancer cell proliferation and invasion via extracellular and intracellular signaling mechanisms. Exp. Mol. Pathol. 2013, 95, 105-110. [CrossRef] [PubMed]

38. Mhawech-Fauceglia, P.; Yan, L.; Sharifian, M.; Ren, X.; Liu, S.; Kim, G.; Gayther, S.A.; Pejovic, T.; Lawrenson, K. Stromal expression of fibroblast activation protein alpha (fap) predicts platinum resistance and shorter recurrence in patients with epithelial ovarian cancer. Cancer Microenviron. 2015, 8, 23-31. [CrossRef] [PubMed] 
39. Cai, J.; Tang, H.; Xu, L.; Wang, X.; Yang, C.; Ruan, S.; Guo, J.; Hu, S.; Wang, Z. Fibroblasts in omentum activated by tumor cells promote ovarian cancer growth, adhesion and invasiveness. Carcinogenesis 2012, 33, 20-29. [CrossRef] [PubMed]

40. Zhang, Y.; Ertl, H.C.J. Depletion of fap $(+)$ cells reduces immunosuppressive cells and improves metabolism and functions cd8(+)t cells within tumors. Oncotarget 2016, 7, 23282-23299. [CrossRef] [PubMed]

41. Kraman, M.; Bambrough, P.J.; Arnold, J.N.; Roberts, E.W.; Magiera, L.; Jones, J.O.; Gopinathan, A.; Tuveson, D.A.; Fearon, D.T. Suppression of antitumor immunity by stromal cells expressing fibroblast activation protein-alpha. Science 2010, 330, 827-830. [CrossRef] [PubMed]

42. Cheng, J.D.; Valianou, M.; Canutescu, A.A.; Jaffe, E.K.; Lee, H.O.; Wang, H.; Lai, J.H.; Bachovchin, W.W.; Weiner, L.M. Abrogation of fibroblast activation protein enzymatic activity attenuates tumor growth. Mol. Cancer Ther. 2005, 4, 351-360. [PubMed]

43. Kelly, T. Fibroblast activation protein-alpha and dipeptidyl peptidase iv (cd26): Cell-surface proteases that activate cell signaling and are potential targets for cancer therapy. Drug Resist. Updat. 2005, 8, 51-58. [CrossRef] [PubMed]

44. Wen, Y.; Wang, C.T.; Ma, T.T.; Li, Z.Y.; Zhou, L.N.; Mu, B.; Leng, F.; Shi, H.S.; Li, Y.O.; Wei, Y.Q. Immunotherapy targeting fibroblast activation protein inhibits tumor growth and increases survival in a murine colon cancer model. Cancer Sci. 2010, 101, 2325-2332. [CrossRef] [PubMed]

45. Fabregat, I.; Fernando, J.; Mainez, J.; Sancho, P. Tgf-beta signaling in cancer treatment. Curr. Pharm. Des. 2014, 20, 2934-2947. [CrossRef] [PubMed]

46. Akhurst, R.J. Targeting tgf-beta signaling for therapeutic gain. Cold Spring Harb. Perspect. Biol. 2017, 9, a022301. [CrossRef] [PubMed]

47. Abendstein, B.; Stadlmann, S.; Knabbe, C.; Buck, M.; Muller-Holzner, E.; Zeimet, A.G.; Marth, C.; Obrist, P.; Krugmann, J.; Offner, F.A. Regulation of transforming growth factor-beta secretion by human peritoneal mesothelial and ovarian carcinoma cells. Cytokine 2000, 12, 1115-1119. [CrossRef] [PubMed]

48. Yamamura, S.; Matsumura, N.; Mandai, M.; Huang, Z.; Oura, T.; Baba, T.; Hamanishi, J.; Yamaguchi, K.; Kang, H.S.; Okamoto, T.; et al. The activated transforming growth factor-beta signaling pathway in peritoneal metastases is a potential therapeutic target in ovarian cancer. Int. J. Cancer 2012, 130, 20-28. [CrossRef] [PubMed]

49. Maier, A.; Peille, A.L.; Vuaroqueaux, V.; Lahn, M. Anti-tumor activity of the tgf-beta receptor kinase inhibitor galunisertib (ly2157299 monohydrate) in patient-derived tumor xenografts. Cell Oncol. (Dordr.) 2015, 38, 131-144. [CrossRef] [PubMed]

50. Gao, Y.; Shan, N.; Zhao, C.; Wang, Y.; Xu, F.; Li, J.; Yu, X.; Gao, L.; Yi, Z. Ly2109761 enhances cisplatin antitumor activity in ovarian cancer cells. Int. J. Clin. Exp. Pathol. 2015, 8, 4923-4932. [PubMed]

51. Kovacs, R.J.; Maldonado, G.; Azaro, A.; Fernandez, M.S.; Romero, F.L.; Sepulveda-Sanchez, J.M.; Corretti, M.; Carducci, M.; Dolan, M.; Gueorguieva, I.; et al. Cardiac safety of tgf-beta receptor i kinase inhibitor ly2157299 monohydrate in cancer patients in a first-in-human dose study. Cardiovasc. Toxicol. 2015, 15, 309-323. [CrossRef] [PubMed]

52. Zhang, M.J.; Liu, T.B.; Xia, B.R.; Yang, C.Y.; Hou, S.Y.; Xie, W.L.; Lou, G. Platelet-derived growth factor d is a prognostic biomarker and is associated with platinum resistance in epithelial ovarian cancer. Int. J. Gynecol. Cancer 2018, 28, 323-331. [CrossRef] [PubMed]

53. Matei, D.; Chang, D.D.; Jeng, M.H. Imatinib mesylate (gleevec) inhibits ovarian cancer cell growth through a mechanism dependent on platelet-derived growth factor receptor alpha and akt inactivation. Clin. Cancer Res. 2004, 10, 681-690. [CrossRef] [PubMed]

54. Pietras, K.; Pahler, J.; Bergers, G.; Hanahan, D. Functions of paracrine pdgf signaling in the proangiogenic tumor stroma revealed by pharmacological targeting. PLoS Med. 2008, 5, e19. [CrossRef] [PubMed]

55. Haubeiss, S.; Schmid, J.O.; Murdter, T.E.; Sonnenberg, M.; Friedel, G.; van der Kuip, H.; Aulitzky, W.E. Dasatinib reverses cancer-associated fibroblasts (cafs) from primary lung carcinomas to a phenotype comparable to that of normal fibroblasts. Mol. Cancer 2010, 9, 1-8. [CrossRef] [PubMed]

56. Matei, D.; Emerson, R.E.; Schilder, J.; Menning, N.; Baldridge, L.A.; Johnson, C.S.; Breen, T.; McClean, J.; Stephens, D.; Whalen, C.; et al. Imatinib mesylate in combination with docetaxel for the treatment of patients with advanced, platinum-resistant ovarian cancer and primary peritoneal carcinomatosis: A hoosier oncology group trial. Cancer 2008, 113, 723-732. [CrossRef] [PubMed] 
57. Matei, D.; Sill, M.W.; Lankes, H.A.; DeGeest, K.; Bristow, R.E.; Mutch, D.; Yamada, S.D.; Cohn, D.; Calvert, V.; Farley, J.; et al. Activity of sorafenib in recurrent ovarian cancer and primary peritoneal carcinomatosis: A gynecologic oncology group trial. J. Clin. Oncol. 2011, 29, 69-75. [CrossRef] [PubMed]

58. Otrock, Z.K.; Mahfouz, R.A.; Makarem, J.A.; Shamseddine, A.I. Understanding the biology of angiogenesis: Review of the most important molecular mechanisms. Blood Cells Mol. Dis. 2007, 39, 212-220. [CrossRef] [PubMed]

59. Folkman, J. Angiogenesis: An organizing principle for drug discovery? Nat. Rev. Drug Discov. 2007, 6, 273-286. [CrossRef] [PubMed]

60. Zetter, B.R. Angiogenesis and tumor metastasis. Annu. Rev. Med. 1998, 49, 407-424. [CrossRef] [PubMed]

61. Hollingsworth, H.C.; Kohn, E.C.; Steinberg, S.M.; Rothenberg, M.L.; Merino, M.J. Tumor angiogenesis in advanced stage ovarian carcinoma. Am. J. Pathol. 1995, 147, 33-41. [PubMed]

62. Hanahan, D.; Folkman, J. Patterns and emerging mechanisms of the angiogenic switch during tumorigenesis. Cell 1996, 86, 353-364. [CrossRef]

63. Ko, S.Y.; Naora, H. Therapeutic strategies for targeting the ovarian tumor stroma. World J. Clin. Cases 2014, 2, 194-200. [CrossRef] [PubMed]

64. Yoneda, J.; Kuniyasu, H.; Crispens, M.A.; Price, J.E.; Bucana, C.D.; Fidler, I.J. Expression of angiogenesis-related genes and progression of human ovarian carcinomas in nude mice. J. Natl. Cancer Inst. 1998, 90, 447-454. [CrossRef] [PubMed]

65. Barton, D.P.; Cai, A.; Wendt, K.; Young, M.; Gamero, A.; De Cesare, S. Angiogenic protein expression in advanced epithelial ovarian cancer. Clin. Cancer Res. 1997, 3, 1579-1586. [PubMed]

66. Kraft, A.; Weindel, K.; Ochs, A.; Marth, C.; Zmija, J.; Schumacher, P.; Unger, C.; Marme, D.; Gastl, G. Vascular endothelial growth factor in the sera and effusions of patients with malignant and nonmalignant disease. Cancer 1999, 85, 178-187. [CrossRef]

67. Mesiano, S.; Ferrara, N.; Jaffe, R.B. Role of vascular endothelial growth factor in ovarian cancer: Inhibition of ascites formation by immunoneutralization. Am. J. Pathol. 1998, 153, 1249-1256. [CrossRef]

68. Shen, G.H.; Ghazizadeh, M.; Kawanami, O.; Shimizu, H.; Jin, E.; Araki, T.; Sugisaki, Y. Prognostic significance of vascular endothelial growth factor expression in human ovarian carcinoma. Br. J. Cancer 2000, 83, 196-203. [CrossRef] [PubMed]

69. Duncan, T.J.; Al-Attar, A.; Rolland, P.; Scott, I.V.; Deen, S.; Liu, D.T.; Spendlove, I.; Durrant, L.G. Vascular endothelial growth factor expression in ovarian cancer: A model for targeted use of novel therapies? Clin. Cancer Res. 2008, 14, 3030-3035. [CrossRef] [PubMed]

70. Graybill, W.; Sood, A.K.; Monk, B.J.; Coleman, R.L. State of the science: Emerging therapeutic strategies for targeting angiogenesis in ovarian cancer. Gynecol. Oncol. 2015, 138, 223-226. [CrossRef] [PubMed]

71. Ruscito, I.; Cacsire Castillo-Tong, D.; Vergote, I.; Ignat, I.; Stanske, M.; Vanderstichele, A.; Glajzer, J.; Kulbe, H.; Trillsch, F.; Mustea, A.; et al. Characterisation of tumour microvessel density during progression of high-grade serous ovarian cancer: Clinico-pathological impact (an octips consortium study). Br. J. Cancer 2018, 119, 330-338. [CrossRef] [PubMed]

72. De Palma, M.; Biziato, D.; Petrova, T.V. Microenvironmental regulation of tumour angiogenesis. Nat. Rev. Cancer 2017, 17, 457-474. [CrossRef] [PubMed]

73. Holmes, D.I.; Zachary, I. The vascular endothelial growth factor (vegf) family: Angiogenic factors in health and disease. Genome Biol. 2005, 6, 209. [CrossRef] [PubMed]

74. Neufeld, G.; Cohen, T.; Gengrinovitch, S.; Poltorak, Z. Vascular endothelial growth factor (vegf) and its receptors. FASEB J. 1999, 13, 9-22. [CrossRef] [PubMed]

75. Gupta, K.; Kshirsagar, S.; Li, W.; Gui, L.; Ramakrishnan, S.; Gupta, P.; Law, P.Y.; Hebbel, R.P. Vegf prevents apoptosis of human microvascular endothelial cells via opposing effects on mapk/erk and sapk/jnk signaling. Exp. Cell Res. 1999, 247, 495-504. [CrossRef] [PubMed]

76. Cebe-Suarez, S.; Zehnder-Fjallman, A.; Ballmer-Hofer, K. The role of vegf receptors in angiogenesis; complex partnerships. Cell. Mol. Life Sci. 2006, 63, 601-615. [CrossRef] [PubMed]

77. Eskander, R.N.; Randall, L.M. Bevacizumab in the treatment of ovarian cancer. Biologics 2011, 5, 1-5. [PubMed]

78. Mabuchi, S.; Terai, Y.; Morishige, K.; Tanabe-Kimura, A.; Sasaki, H.; Kanemura, M.; Tsunetoh, S.; Tanaka, Y.; Sakata, M.; Burger, R.A.; et al. Maintenance treatment with bevacizumab prolongs survival in an in vivo ovarian cancer model. Clin. Cancer Res. 2008, 14, 7781-7789. [CrossRef] [PubMed] 
79. Burger, R.A.; Brady, M.F.; Bookman, M.A.; Fleming, G.F.; Monk, B.J.; Huang, H.; Mannel, R.S.; Homesley, H.D.; Fowler, J.; Greer, B.E.; et al. Incorporation of bevacizumab in the primary treatment of ovarian cancer. N. Engl. J. Med. 2011, 365, 2473-2483. [CrossRef] [PubMed]

80. Coleman, R.L.; Brady, M.F.; Herzog, T.J.; Sabbatini, P.; Armstrong, D.K.; Walker, J.L.; Kim, B.G.; Fujiwara, K.; Tewari, K.S.; O'Malley, D.M.; et al. Bevacizumab and paclitaxel-carboplatin chemotherapy and secondary cytoreduction in recurrent, platinum-sensitive ovarian cancer (nrg oncology/gynecologic oncology group study gog-0213): A multicentre, open-label, randomised, phase 3 trial. Lancet Oncol. 2017, 18, 779-791. [CrossRef]

81. Burger, R.A.; Sill, M.W.; Monk, B.J.; Greer, B.E.; Sorosky, J.I. Phase II trial of bevacizumab in persistent or recurrent epithelial ovarian cancer or primary peritoneal cancer: A gynecologic oncology group study. $J$. Clin. Oncol. 2007, 25, 5165-5171. [CrossRef] [PubMed]

82. Perren, T.J.; Swart, A.M.; Pfisterer, J.; Ledermann, J.A.; Pujade-Lauraine, E.; Kristensen, G.; Carey, M.S.; Beale, P.; Cervantes, A.; Kurzeder, C.; et al. A phase 3 trial of bevacizumab in ovarian cancer. N. Engl. J. Med. 2011, 365, 2484-2496. [CrossRef] [PubMed]

83. Pujade-Lauraine, E.; Hilpert, F.; Weber, B.; Reuss, A.; Poveda, A.; Kristensen, G.; Sorio, R.; Vergote, I.; Witteveen, P.; Bamias, A.; et al. Bevacizumab combined with chemotherapy for platinum-resistant recurrent ovarian cancer: The aurelia open-label randomized phase iii trial. J. Clin. Oncol. 2014, 32, 1302-1308. [CrossRef] [PubMed]

84. Moroney, J.W.; Sood, A.K.; Coleman, R.L. Aflibercept in epithelial ovarian carcinoma. Future Oncol. 2009, 5, 591-600. [CrossRef] [PubMed]

85. Teng, L.S.; Jin, K.T.; He, K.F.; Zhang, J.; Wang, H.H.; Cao, J. Clinical applications of vegf-trap (aflibercept) in cancer treatment. J. Chin. Med. Assoc. 2010, 73, 449-456. [CrossRef]

86. Byrne, A.T.; Ross, L.; Holash, J.; Nakanishi, M.; Hu, L.; Hofmann, J.I.; Yancopoulos, G.D.; Jaffe, R.B. Vascular endothelial growth factor-trap decreases tumor burden, inhibits ascites, and causes dramatic vascular remodeling in an ovarian cancer model. Clin. Cancer Res. 2003, 9, 5721-5728. [PubMed]

87. Colombo, N.; Mangili, G.; Mammoliti, S.; Kalling, M.; Tholander, B.; Sternas, L.; Buzenet, G.; Chamberlain, D. A phase ii study of aflibercept in patients with advanced epithelial ovarian cancer and symptomatic malignant ascites. Gynecol. Oncol. 2012, 125, 42-47. [CrossRef] [PubMed]

88. Bergers, G.; Hanahan, D. Modes of resistance to anti-angiogenic therapy. Nat. Rev. Cancer 2008, 8, $592-603$. [CrossRef] [PubMed]

89. Matulonis, U.A.; Berlin, S.; Ivy, P.; Tyburski, K.; Krasner, C.; Zarwan, C.; Berkenblit, A.; Campos, S.; Horowitz, N.; Cannistra, S.A.; et al. Cediranib, an oral inhibitor of vascular endothelial growth factor receptor kinases, is an active drug in recurrent epithelial ovarian, fallopian tube, and peritoneal cancer. J. Clin. Oncol. 2009, 27, 5601-5606. [CrossRef] [PubMed]

90. Hirte, H.; Lheureux, S.; Fleming, G.F.; Sugimoto, A.; Morgan, R.; Biagi, J.; Wang, L.; McGill, S.; Ivy, S.P.; Oza, A.M. A phase 2 study of cediranib in recurrent or persistent ovarian, peritoneal or fallopian tube cancer: A trial of the princess margaret, chicago and california phase ii consortia. Gynecol. Oncol. 2015, 138, 55-61. [CrossRef] [PubMed]

91. Ledermann, J.A.; Hackshaw, A.; Kaye, S.; Jayson, G.; Gabra, H.; McNeish, I.; Earl, H.; Perren, T.; Gore, M.; Persic, M.; et al. Randomized phase ii placebo-controlled trial of maintenance therapy using the oral triple angiokinase inhibitor bibf 1120 after chemotherapy for relapsed ovarian cancer. J. Clin. Oncol. 2011, 29, 3798-3804. [CrossRef] [PubMed]

92. Du Bois, A.; Kristensen, G.; Ray-Coquard, I.; Reuss, A.; Pignata, S.; Colombo, N.; Denison, U.; Vergote, I.; del Campo, J.M.; Ottevanger, P.; et al. Standard first-line chemotherapy with or without nintedanib for advanced ovarian cancer (ago-ovar 12): A randomised, double-blind, placebo-controlled phase 3 trial. Lancet Oncol. 2016, 17, 78-89. [CrossRef]

93. Pignata, S.; Lorusso, D.; Scambia, G.; Sambataro, D.; Tamberi, S.; Cinieri, S.; Mosconi, A.M.; Orditura, M.; Bartolini, S.; Arcangeli, V.; et al. Mito-11: A randomized multicenter phase ii trial testing the addition of pazopanib to weekly paclitaxel in platinum-resistant or -refractory advanced ovarian cancer (aoc). J. Clin. Oncol. 2014, 32.

94. Sawada, K.; Mitra, A.K.; Radjabi, A.R.; Bhaskar, V.; Kistner, E.O.; Tretiakova, M.; Jagadeeswaran, S.; Montag, A.; Becker, A.; Kenny, H.A.; et al. Loss of e-cadherin promotes ovarian cancer metastasis via alpha 5-integrin, which is a therapeutic target. Cancer Res. 2008, 68, 2329-2339. [CrossRef] [PubMed] 
95. Iwanicki, M.P.; Davidowitz, R.A.; Ng, M.R.; Besser, A.; Muranen, T.; Merritt, M.; Danuser, G.; Ince, T.A.; Brugge, J.S. Ovarian cancer spheroids use myosin-generated force to clear the mesothelium. Cancer Discov. 2011, 1, 144-157. [CrossRef] [PubMed]

96. Davidowitz, R.A.; Selfors, L.M.; Iwanicki, M.P.; Elias, K.M.; Karst, A.; Piao, H.; Ince, T.A.; Drage, M.G.; Dering, J.; Konecny, G.E.; et al. Mesenchymal gene program-expressing ovarian cancer spheroids exhibit enhanced mesothelial clearance. J. Clin. Investig. 2014, 124, 2611-2625. [CrossRef] [PubMed]

97. Lessan, K.; Aguiar, D.J.; Oegema, T.; Siebenson, L.; Skubitz, A.P. Cd44 and beta1 integrin mediate ovarian carcinoma cell adhesion to peritoneal mesothelial cells. Am. J. Pathol. 1999, 154, 1525-1537. [CrossRef]

98. Kenny, H.A.; Chiang, C.Y.; White, E.A.; Schryver, E.M.; Habis, M.; Romero, I.L.; Ladanyi, A.; Penicka, C.V.; George, J.; Matlin, K.; et al. Mesothelial cells promote early ovarian cancer metastasis through fibronectin secretion. J. Clin. Investig. 2014, 124, 4614-4628. [CrossRef] [PubMed]

99. Janiak, A.; Zemskov, E.A.; Belkin, A.M. Cell surface transglutaminase promotes rhoa activation via integrin clustering and suppression of the src-p190rhogap signaling pathway. Mol. Biol. Cell 2006, 17, 1606-1619. [CrossRef] [PubMed]

100. Satpathy, M.; Cao, L.; Pincheira, R.; Emerson, R.; Bigsby, R.; Nakshatri, H.; Matei, D. Enhanced peritoneal ovarian tumor dissemination by tissue transglutaminase. Cancer Res. 2007, 67, 7194-7202. [CrossRef] [PubMed]

101. Shao, M.; Cao, L.; Shen, C.; Satpathy, M.; Chelladurai, B.; Bigsby, R.M.; Nakshatri, H.; Matei, D. Epithelial-to-mesenchymal transition and ovarian tumor progression induced by tissue transglutaminase. Cancer Res. 2009, 69, 9192-9201. [CrossRef] [PubMed]

102. Condello, S.; Cao, L.; Matei, D. Tissue transglutaminase regulates beta-catenin signaling through a c-src-dependent mechanism. FASEB J. 2013, 27, 3100-3112. [CrossRef] [PubMed]

103. Condello, S.; Sima, L.; Ivan, C.; Cardenas, H.; Schiltz, G.; Mishra, R.K.; Matei, D. Tissue tranglutaminase regulates interactions between ovarian cancer stem cells and the tumor niche. Cancer Res. 2018, 78, 2990-3001. [CrossRef] [PubMed]

104. Strobel, T.; Cannistra, S.A. Beta1-integrins partly mediate binding of ovarian cancer cells to peritoneal mesothelium in vitro. Gynecol. Oncol. 1999, 73, 362-367. [CrossRef] [PubMed]

105. Cannistra, S.A.; Kansas, G.S.; Niloff, J.; DeFranzo, B.; Kim, Y.; Ottensmeier, C. Binding of ovarian cancer cells to peritoneal mesothelium in vitro is partly mediated by cd44h. Cancer Res. 1993, 53, 3830-3838. [PubMed]

106. Strobel, T.; Swanson, L.; Cannistra, S.A. In vivo inhibition of cd44 limits intra-abdominal spread of a human ovarian cancer xenograft in nude mice: A novel role for $\mathrm{cd} 44$ in the process of peritoneal implantation. Cancer Res. 1997, 57, 1228-1232. [PubMed]

107. Slack-Davis, J.K.; Atkins, K.A.; Harrer, C.; Hershey, E.D.; Conaway, M. Vascular cell adhesion molecule-1 is a regulator of ovarian cancer peritoneal metastasis. Cancer Res. 2009, 69, 1469-1476. [CrossRef] [PubMed]

108. Mitra, A.K.; Sawada, K.; Tiwari, P.; Mui, K.; Gwin, K.; Lengyel, E. Ligand-independent activation of c-met by fibronectin and alpha(5)beta(1)-integrin regulates ovarian cancer invasion and metastasis. Oncogene 2011, 30, 1566-1576. [CrossRef] [PubMed]

109. Raab-Westphal, S.; Marshall, J.F.; Goodman, S.L. Integrins as therapeutic targets: Successes and cancers. Cancers (Basel) 2017, 9, 110. [CrossRef] [PubMed]

110. Bell-McGuinn, K.M.; Matthews, C.M.; Ho, S.N.; Barve, M.; Gilbert, L.; Penson, R.T.; Lengyel, E.; Palaparthy, R.; Gilder, K.; Vassos, A.; et al. A phase ii, single-arm study of the anti-alpha5beta1 integrin antibody volociximab as monotherapy in patients with platinum-resistant advanced epithelial ovarian or primary peritoneal cancer. Gynecol. Oncol. 2011, 121, 273-279. [CrossRef] [PubMed]

111. Trikha, M.; Zhou, Z.; Nemeth, J.A.; Chen, Q.; Sharp, C.; Emmell, E.; Giles-Komar, J.; Nakada, M.T. Cnto 95, a fully human monoclonal antibody that inhibits alphav integrins, has antitumor and antiangiogenic activity in vivo. Int. J. Cancer 2004, 110, 326-335. [CrossRef] [PubMed]

112. Chen, Q.; Manning, C.D.; Millar, H.; McCabe, F.L.; Ferrante, C.; Sharp, C.; Shahied-Arruda, L.; Doshi, P.; Nakada, M.T.; Anderson, G.M. Cnto 95, a fully human anti alphav integrin antibody, inhibits cell signaling, migration, invasion, and spontaneous metastasis of human breast cancer cells. Clin. Exp. Metastasis 2008, 25, 139-148. [CrossRef] [PubMed]

113. Mullamitha, S.A.; Ton, N.C.; Parker, G.J.; Jackson, A.; Julyan, P.J.; Roberts, C.; Buonaccorsi, G.A.; Watson, Y.; Davies, K.; Cheung, S.; et al. Phase i evaluation of a fully human anti-alphav integrin monoclonal antibody (cnto 95) in patients with advanced solid tumors. Clin. Cancer Res. 2007, 13, 2128-2135. [CrossRef] [PubMed] 
114. Hersey, P.; Sosman, J.; O’Day, S.; Richards, J.; Bedikian, A.; Gonzalez, R.; Sharfman, W.; Weber, R.; Logan, T.; Buzoianu, M.; et al. A randomized phase 2 study of etaracizumab, a monoclonal antibody against integrin alpha(v)beta(3), + or - dacarbazine in patients with stage iv metastatic melanoma. Cancer 2010, 116, 1526-1534. [CrossRef] [PubMed]

115. Dolgos, H.; Freisleben, A.; Wimmer, E.; Scheible, H.; Kratzer, F.; Yamagata, T.; Gallemann, D.; Fluck, M. In vitro and in vivo drug disposition of cilengitide in animals and human. Pharmacol. Res. Perspect. 2016, 4, e00217. [CrossRef] [PubMed]

116. Soffietti, R.; Trevisan, E.; Ruda, R. What have we learned from trials on antiangiogenic agents in glioblastoma? Expert Rev. Neurother. 2014, 14, 1-3. [CrossRef] [PubMed]

117. Kaur, S.; Kenny, H.A.; Jagadeeswaran, S.; Zillhardt, M.R.; Montag, A.G.; Kistner, E.; Yamada, S.D.; Mitra, A.K.; Lengyel, E. \{beta\}3-integrin expression on tumor cells inhibits tumor progression, reduces metastasis, and is associated with a favorable prognosis in patients with ovarian cancer. Am. J. Pathol. 2009, 175, 2184-2196. [CrossRef] [PubMed]

118. Kenny, H.A.; Lengyel, E. Mmp-2 functions as an early response protein in ovarian cancer metastasis. Cell Cycle 2009, 8, 683-688. [CrossRef] [PubMed]

119. Schlaepfer, D.D.; Jones, K.C.; Hunter, T. Multiple grb2-mediated integrin-stimulated signaling pathways to erk2/mitogen-activated protein kinase: Summation of both c-src- and focal adhesion kinase-initiated tyrosine phosphorylation events. Mol. Cell Biol. 1998, 18, 2571-2585. [CrossRef] [PubMed]

120. Renshaw, M.W.; Price, L.S.; Schwartz, M.A. Focal adhesion kinase mediates the integrin signaling requirement for growth factor activation of map kinase. J. Cell Biol. 1999, 147, 611-618. [CrossRef] [PubMed]

121. Ward, K.K.; Tancioni, I.; Lawson, C.; Miller, N.L.; Jean, C.; Chen, X.L.; Uryu, S.; Kim, J.; Tarin, D.; Stupack, D.G.; et al. Inhibition of focal adhesion kinase (fak) activity prevents anchorage-independent ovarian carcinoma cell growth and tumor progression. Clin. Exp. Metastasis 2013, 30, 579-594. [CrossRef] [PubMed]

122. Matei, D.; Graeber, T.G.; Baldwin, R.L.; Karlan, B.Y.; Rao, J.; Chang, D.D. Gene expression in epithelial ovarian carcinoma. Oncogene 2002, 21, 6289-6298. [CrossRef] [PubMed]

123. Yakubov, B.; Chelladurai, B.; Schmitt, J.; Emerson, R.; Turchi, J.J.; Matei, D. Extracellular tissue transglutaminase activates noncanonical nf-kappab signaling and promotes metastasis in ovarian cancer. Neoplasia 2013, 15, 609-619. [CrossRef] [PubMed]

124. Satpathy, M.; Shao, M.; Emerson, R.; Donner, D.B.; Matei, D. Tissue transglutaminase regulates matrix metalloproteinase-2 in ovarian cancer by modulating camp-response element-binding protein activity. J. Biol. Chem. 2009, 284, 15390-15399. [CrossRef] [PubMed]

125. Khanna, M.; Chelladurai, B.; Gavini, A.; Li, L.; Shao, M.; Courtney, D.; Turchi, J.J.; Matei, D.; Meroueh, S. Targeting ovarian tumor cell adhesion mediated by tissue transglutaminase. Mol. Cancer Ther. 2011, 10, 626-636. [CrossRef] [PubMed]

126. Yakubov, B.; Chen, L.; Belkin, A.M.; Zhang, S.; Chelladurai, B.; Zhang, Z.Y.; Matei, D. Small molecule inhibitors target the tissue transglutaminase and fibronectin interaction. PLoS ONE 2014, 9, e89285. [CrossRef] [PubMed]

127. Burkholder, B.; Huang, R.Y.; Burgess, R.; Luo, S.; Jones, V.S.; Zhang, W.; Lv, Z.Q.; Gao, C.Y.; Wang, B.L.; Zhang, Y.M.; et al. Tumor-induced perturbations of cytokines and immune cell networks. Biochim. Biophys. Acta. 2014, 1845, 182-201. [CrossRef] [PubMed]

128. Zhang, L.; Conejo-Garcia, J.R.; Katsaros, D.; Gimotty, P.A.; Massobrio, M.; Regnani, G.; Makrigiannakis, A.; Gray, H.; Schlienger, K.; Liebman, M.N.; et al. Intratumoral t cells, recurrence, and survival in epithelial ovarian cancer. Ne. Engl. J. Med. 2003, 348, 203-213. [CrossRef] [PubMed]

129. Clarke, B.; Tinker, A.V.; Lee, C.H.; Subramanian, S.; van de Rijn, M.; Turbin, D.; Kalloger, S.; Han, G.; Ceballos, K.; Cadungog, M.G.; et al. Intraepithelial t cells and prognosis in ovarian carcinoma: Novel associations with stage, tumor type, and brca1 loss. Mod. Pathol. 2009, 22, 393-402. [CrossRef] [PubMed]

130. Sato, E.; Olson, S.H.; Ahn, J.; Bundy, B.; Nishikawa, H.; Qian, F.; Jungbluth, A.A.; Frosina, D.; Gnjatic, S.; Ambrosone, C.; et al. Intraepithelial cd8+ tumor-infiltrating lymphocytes and a high cd8+/regulatory $t$ cell ratio are associated with favorable prognosis in ovarian cancer. Proc. Natl. Acad. Sci. USA 2005, 102, 18538-18543. [CrossRef] [PubMed] 
131. Santoiemma, P.P.; Reyes, C.; Wang, L.P.; McLane, M.W.; Feldman, M.D.; Tanyi, J.L.; Powell, D.J., Jr. Systematic evaluation of multiple immune markers reveals prognostic factors in ovarian cancer. Gynecol. Oncol. 2016, 143, 120-127. [CrossRef] [PubMed]

132. Ye, Q.; Song, D.G.; Poussin, M.; Yamamoto, T.; Best, A.; Li, C.; Coukos, G.; Powell, D.J., Jr. Cd137 accurately identifies and enriches for naturally occurring tumor-reactive t cells in tumor. Clin. Cancer Res. 2014, 20, 44-55. [CrossRef] [PubMed]

133. Jimenez-Sanchez, A.; Memon, D.; Pourpe, S.; Veeraraghavan, H.; Li, Y.; Vargas, H.A.; Gill, M.B.; Park, K.J.; Zivanovic, O.; Konner, J.; et al. Heterogeneous tumor-immune microenvironments among differentially growing metastases in an ovarian cancer patient. Cell 2017, 170, 927-938. [CrossRef] [PubMed]

134. Bosmuller, H.C.; Wagner, P.; Peper, J.K.; Schuster, H.; Pham, D.L.; Greif, K.; Beschorner, C.; Rammensee, H.G.; Stevanovic, S.; Fend, F.; et al. Combined immunoscore of cd103 and cd3 identifies long-term survivors in high-grade serous ovarian cancer. Int. J. Gynecol. Cancer 2016, 26, 671-679. [CrossRef] [PubMed]

135. Garon, E.B.; Rizvi, N.A.; Hui, R.; Leighl, N.; Balmanoukian, A.S.; Eder, J.P.; Patnaik, A.; Aggarwal, C.; Gubens, M.; Horn, L.; et al. Pembrolizumab for the treatment of non-small-cell lung cancer. N. Engl. J. Med. 2015, 372, 2018-2028. [CrossRef] [PubMed]

136. Robert, C.; Schachter, J.; Long, G.V.; Arance, A.; Grob, J.J.; Mortier, L.; Daud, A.; Carlino, M.S.; McNeil, C.; Lotem, M.; et al. Pembrolizumab versus ipilimumab in advanced melanoma. N. Engl. J. Med. 2015, 372, 2521-2532. [CrossRef] [PubMed]

137. Ikarashi, H.; Fujita, K.; Takakuwa, K.; Kodama, S.; Tokunaga, A.; Takahashi, T.; Tanaka, K. Immunomodulation in patients with epithelial ovarian cancer after adoptive transfer of tumor-infiltrating lymphocytes. Cancer Res. 1994, 54, 190-196. [PubMed]

138. Kandalaft, L.E.; Chiang, C.L.; Tanyi, J.; Motz, G.; Balint, K.; Mick, R.; Coukos, G. A phase i vaccine trial using dendritic cells pulsed with autologous oxidized lysate for recurrent ovarian cancer. J. Transl. Med. 2013, 11, 149. [CrossRef] [PubMed]

139. Tumeh, P.C.; Harview, C.L.; Yearley, J.H.; Shintaku, I.P.; Taylor, E.J.; Robert, L.; Chmielowski, B.; Spasic, M.; Henry, G.; Ciobanu, V.; et al. Pd-1 blockade induces responses by inhibiting adaptive immune resistance. Nature 2014, 515, 568-571. [CrossRef] [PubMed]

140. Brahmer, J.R.; Tykodi, S.S.; Chow, L.Q.; Hwu, W.J.; Topalian, S.L.; Hwu, P.; Drake, C.G.; Camacho, L.H.; Kauh, J.; Odunsi, K.; et al. Safety and activity of anti-pd-11 antibody in patients with advanced cancer. $N$. Engl. J. Med. 2012, 366, 2455-2465. [CrossRef] [PubMed]

141. Gettinger, S.N.; Horn, L.; Gandhi, L.; Spigel, D.R.; Antonia, S.J.; Rizvi, N.A.; Powderly, J.D.; Heist, R.S.; Carvajal, R.D.; Jackman, D.M.; et al. Overall survival and long-term safety of nivolumab (anti-programmed death 1 antibody, bms-936558, ono-4538) in patients with previously treated advanced non-small-cell lung cancer. J. Clin. Oncol. 2015, 33, 2004-2012. [CrossRef] [PubMed]

142. Mahoney, K.M.; Freeman, G.J.; McDermott, D.F. The next immune-checkpoint inhibitors: Pd-1/pd-11 blockade in melanoma. Clin. Ther. 2015, 37, 764-782. [CrossRef] [PubMed]

143. Hamanishi, J.; Mandai, M.; Iwasaki, M.; Okazaki, T.; Tanaka, Y.; Yamaguchi, K.; Higuchi, T.; Yagi, H.; Takakura, K.; Minato, N.; et al. Programmed cell death 1 ligand 1 and tumor-infiltrating cd8+ tymphocytes are prognostic factors of human ovarian cancer. Proc. Natl. Acad. Sci. USA 2007, 104, 3360-3365. [CrossRef] [PubMed]

144. Krempski, J.; Karyampudi, L.; Behrens, M.D.; Erskine, C.L.; Hartmann, L.; Dong, H.; Goode, E.L.; Kalli, K.R.; Knutson, K.L. Tumor-infiltrating programmed death receptor-1+ dendritic cells mediate immune suppression in ovarian cancer. J. Immunol. 2011, 186, 6905-6913. [CrossRef] [PubMed]

145. Darb-Esfahani, S.; Kunze, C.A.; Kulbe, H.; Sehouli, J.; Wienert, S.; Lindner, J.; Budczies, J.; Bockmayr, M.; Dietel, M.; Denkert, C.; et al. Prognostic impact of programmed cell death-1 (pd-1) and pd-ligand 1 (pd-11) expression in cancer cells and tumor-infiltrating lymphocytes in ovarian high grade serous carcinoma. Oncotarget 2016, 7, 1486-1499. [CrossRef] [PubMed]

146. Webb, J.R.; Milne, K.; Kroeger, D.R.; Nelson, B.H. Pd-11 expression is associated with tumor-infiltrating t cells and favorable prognosis in high-grade serous ovarian cancer. Gynecol. Oncol. 2016, 141, 293-302. [CrossRef] [PubMed]

147. Duraiswamy, J.; Freeman, G.J.; Coukos, G. Therapeutic pd-1 pathway blockade augments with other modalities of immunotherapy $\mathrm{t}$-cell function to prevent immune decline in ovarian cancer. Cancer Res. 2013, 73, 6900-6912. [CrossRef] [PubMed] 
148. Varga, A.; Pihapaul, S.A.; Ott, P.A.; Mehnert, J.M.; Bertonrigaud, D.; Johnson, E.A.; Cheng, J.D.; Yuan, S.; Rubin, E.H.; Matei, D.E. Antitumor activity and safety of pembrolizumab in patients (pts) with pd-11 positive advanced ovarian cancer: Interim results from a phase ib study. J. Clin. Oncol. 2015, 33, 5510. [CrossRef]

149. Disis, M.L.; Patel, M.R.; Pant, S.; Infante, J.R.; Lockhart, A.C.; Kelly, K.; Beck, J.T.; Gordon, M.S.; Weiss, G.J.; Ejadi, S.; et al. Avelumab (msb0010718c), an anti-pd-11 antibody, in patients with previously treated, recurrent or refractory ovarian cancer: A phase ib, open-label expansion trial. J. Clin. Oncol. 2015, 33, 5509. [CrossRef]

150. Lau, E. Mismatch repair deficiency predicts benefit of anti-pd-1 therapy. Lancet Oncol. 2015, 16 , e319. [CrossRef]

151. Le, D.T.; Uram, J.N.; Wang, H.; Bartlett, B.R.; Kemberling, H.; Eyring, A.D.; Skora, A.D.; Luber, B.S.; Azad, N.S.; Laheru, D.; et al. Pd-1 blockade in tumors with mismatch-repair deficiency. N. Engl. J. Med. 2015, 372, 2509-2520. [CrossRef] [PubMed]

152. Strickland, K.C.; Howitt, B.E.; Shukla, S.A.; Rodig, S.; Ritterhouse, L.L.; Liu, J.F.; Garber, J.E.; Chowdhury, D.; $\mathrm{Wu}$, C.J.; D'Andrea, A.D.; et al. Association and prognostic significance of brca1/2-mutation status with neoantigen load, number of tumor-infiltrating lymphocytes and expression of pd-1/pd-11 in high grade serous ovarian cancer. Oncotarget 2016, 7, 13587-13598. [CrossRef] [PubMed]

153. Noy, R.; Pollard, J.W. Tumor-associated macrophages: From mechanisms to therapy. Immunity 2014, 41, 49-61. [CrossRef] [PubMed]

154. Rabinovich, G.A.; Gabrilovich, D.; Sotomayor, E.M. Immunosuppressive strategies that are mediated by tumor cells. Annu. Rev. Immunol. 2007, 25, 267-296. [CrossRef] [PubMed]

155. Bronte, V.; Serafini, P.; Apolloni, E.; Zanovello, P. Tumor-induced immune dysfunctions caused by myeloid suppressor cells. J. Immunother. 2001, 24, 431-446. [CrossRef] [PubMed]

156. Almand, B.; Clark, J.I.; Nikitina, E.; van Beynen, J.; English, N.R.; Knight, S.C.; Carbone, D.P.; Gabrilovich, D.I. Increased production of immature myeloid cells in cancer patients: A mechanism of immunosuppression in cancer. J. Immunol. 2001, 166, 678-689. [CrossRef] [PubMed]

157. Youn, J.I.; Nagaraj, S.; Collazo, M.; Gabrilovich, D.I. Subsets of myeloid-derived suppressor cells in tumor-bearing mice. J. Immunol. 2008, 181, 5791-5802. [CrossRef] [PubMed]

158. Zhang, M.; He, Y.; Sun, X.; Li, Q.; Wang, W.; Zhao, A.; Di, W. A high $\mathrm{m} 1 / \mathrm{m} 2$ ratio of tumor-associated macrophages is associated with extended survival in ovarian cancer patients. J. Ovarian Res. 2014, 7, 19. [CrossRef] [PubMed]

159. Pollard, J.W. Tumour-educated macrophages promote tumour progression and metastasis. Nat. Rev. Cancer 2004, 4, 71-78. [CrossRef] [PubMed]

160. Wang, X.; Deavers, M.; Patenia, R.; Bassett, R.L., Jr.; Mueller, P.; Ma, Q.; Wang, E.; Freedman, R.S. Monocyte/macrophage and $\mathrm{t}$-cell infiltrates in peritoneum of patients with ovarian cancer or benign pelvic disease. J. Transl. Med. 2006, 4, 30. [CrossRef] [PubMed]

161. Yin, M.; Li, X.; Tan, S.; Zhou, H.J.; Ji, W.; Bellone, S.; Xu, X.; Zhang, H.; Santin, A.D.; Lou, G.; et al. Tumor-associated macrophages drive spheroid formation during early transcoelomic metastasis of ovarian cancer. J. Clin. Investig. 2016, 126, 4157-4173. [CrossRef] [PubMed]

162. Hagemann, T.; Wilson, J.; Kulbe, H.; Li, N.F.; Leinster, D.A.; Charles, K.; Klemm, F.; Pukrop, T.; Binder, C.; Balkwill, F.R. Macrophages induce invasiveness of epithelial cancer cells via nf-kappa b and jnk. J. Immunol. 2005, 175, 1197-1205. [CrossRef] [PubMed]

163. Ko, S.Y.; Ladanyi, A.; Lengyel, E.; Naora, H. Expression of the homeobox gene hoxa9 in ovarian cancer induces peritoneal macrophages to acquire an $\mathrm{m} 2$ tumor-promoting phenotype. Am. J. Pathol. 2014, 184, 271-281. [CrossRef] [PubMed]

164. Cui, T.X.; Kryczek, I.; Zhao, L.; Zhao, E.; Kuick, R.; Roh, M.H.; Vatan, L.; Szeliga, W.; Mao, Y.; Thomas, D.G.; et al. Myeloid-derived suppressor cells enhance stemness of cancer cells by inducing microrna101 and suppressing the corepressor ctbp2. Immunity 2013, 39, 611-621. [CrossRef] [PubMed]

165. Horikawa, N.; Abiko, K.; Matsumura, N.; Hamanishi, J.; Baba, T.; Yamaguchi, K.; Yoshioka, Y.; Koshiyama, M.; Konishi, I. Expression of vascular endothelial growth factor in ovarian cancer inhibits tumor immunity through the accumulation of myeloid-derived suppressor cells. Clin. Cancer Res. 2017, 23, 587-599. [CrossRef] [PubMed]

166. Taki, M.; Abiko, K.; Baba, T.; Hamanishi, J.; Yamaguchi, K.; Murakami, R.; Yamanoi, K.; Horikawa, N.; Hosoe, Y.; Nakamura, E.; et al. Snail promotes ovarian cancer progression by recruiting myeloid-derived suppressor cells via cxcr2 ligand upregulation. Nat. Commun. 2018, 9, 1685. [CrossRef] [PubMed] 
167. De Sanctis, F.; Bronte, V.; Ugel, S. Tumor-induced myeloid-derived suppressor cells. Microbiol. Spectr. 2016, 4. [CrossRef] [PubMed]

168. Engblom, C.; Pfirschke, C.; Pittet, M.J. The role of myeloid cells in cancer therapies. Nat. Rev. Cancer 2016, 16, 447-462. [CrossRef] [PubMed]

169. Pulaski, H.L.; Spahlinger, G.; Silva, I.A.; McLean, K.; Kueck, A.S.; Reynolds, R.K.; Coukos, G.; Conejo-Garcia, J.R.; Buckanovich, R.J. Identifying alemtuzumab as an anti-myeloid cell antiangiogenic therapy for the treatment of ovarian cancer. J. Transl. Med. 2009, 7, 49. [CrossRef] [PubMed]

170. Penn, C.A.; Yang, K.; Zong, H.; Lim, J.Y.; Cole, A.; Yang, D.; Baker, J.; Goonewardena, S.N.; Buckanovich, R.J. Therapeutic impact of nanoparticle therapy targeting tumor-associated macrophages. Mol. Cancer Ther. 2018, 17, 96-106. [CrossRef] [PubMed]

171. Zhu, H.; Bengsch, F.; Svoronos, N.; Rutkowski, M.R.; Bitler, B.G.; Allegrezza, M.J.; Yokoyama, Y.; Kossenkov, A.V.; Bradner, J.E.; Conejo-Garcia, J.R.; et al. Bet bromodomain inhibition promotes anti-tumor immunity by suppressing pd-11 expression. Cell Rep. 2016, 16, 2829-2837. [CrossRef] [PubMed]

172. Stone, M.L.; Chiappinelli, K.B.; Li, H.; Murphy, L.M.; Travers, M.E.; Topper, M.J.; Mathios, D.; Lim, M.; Shih, I.M.; Wang, T.L.; et al. Epigenetic therapy activates type i interferon signaling in murine ovarian cancer to reduce immunosuppression and tumor burden. Proc. Natl. Acad. Sci. USA 2017, 114, E10981-E10990. [CrossRef] [PubMed]

173. Burges, A.; Wimberger, P.; Kumper, C.; Gorbounova, V.; Sommer, H.; Schmalfeldt, B.; Pfisterer, J.; Lichinitser, M.; Makhson, A.; Moiseyenko, V.; et al. Effective relief of malignant ascites in patients with advanced ovarian cancer by a trifunctional anti-epcam $x$ anti-cd3 antibody: A phase i/ii study. Clin. Cancer Res. 2007, 13, 3899-3905. [CrossRef] [PubMed]

(C) 2018 by the authors. Licensee MDPI, Basel, Switzerland. This article is an open access article distributed under the terms and conditions of the Creative Commons Attribution (CC BY) license (http:/ / creativecommons.org/licenses/by/4.0/). 